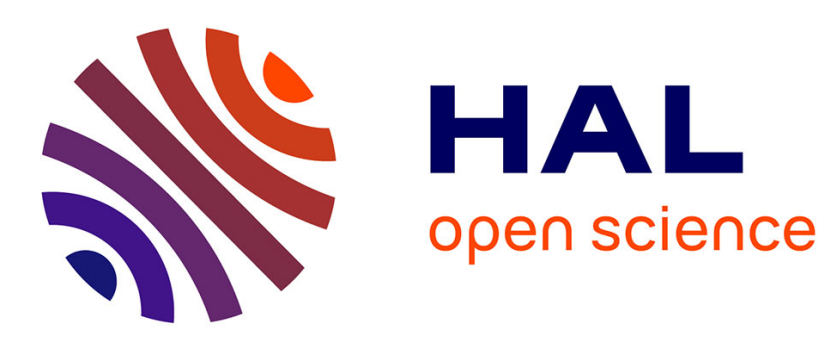

\title{
Endogenous Technology Adoption and Medical Costs
}

Karine Lamiraud, Stéphane Lhuillery

\section{To cite this version:}

Karine Lamiraud, Stéphane Lhuillery. Endogenous Technology Adoption and Medical Costs. Health Economics, 2016, 25 (9), pp.1123-1147. 10.1002/hec.3361 . hal-01512885v2

\section{HAL Id: hal-01512885 \\ https://hal.science/hal-01512885v2}

Submitted on 11 Apr 2023

HAL is a multi-disciplinary open access archive for the deposit and dissemination of scientific research documents, whether they are published or not. The documents may come from teaching and research institutions in France or abroad, or from public or private research centers.
L'archive ouverte pluridisciplinaire HAL, est destinée au dépôt et à la diffusion de documents scientifiques de niveau recherche, publiés ou non, émanant des établissements d'enseignement et de recherche français ou étrangers, des laboratoires publics ou privés. 


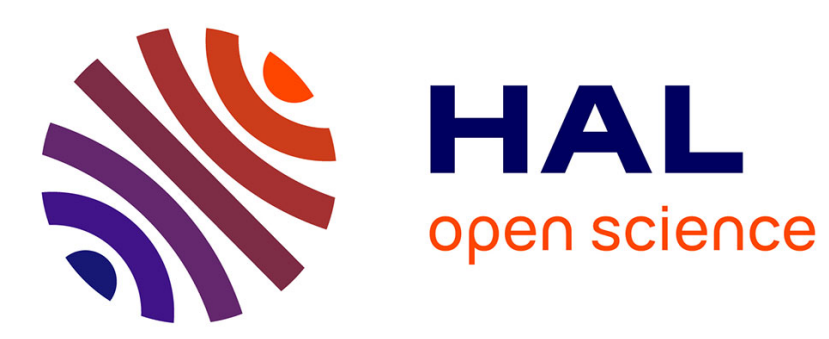

\section{Endogenous Technology Adoption and Medical Costs}

Karine Lamiraud, Stéphane Lhuillery

\section{To cite this version:}

Karine Lamiraud, Stéphane Lhuillery. Endogenous Technology Adoption and Medical Costs. 2015. hal-01218064

\section{HAL Id: hal-01218064 \\ https://essec.hal.science/hal-01218064}

Preprint submitted on 20 Oct 2015

HAL is a multi-disciplinary open access archive for the deposit and dissemination of scientific research documents, whether they are published or not. The documents may come from teaching and research institutions in France or abroad, or from public or private research centers.
L'archive ouverte pluridisciplinaire HAL, est destinée au dépôt et à la diffusion de documents scientifiques de niveau recherche, publiés ou non, émanant des établissements d'enseignement et de recherche français ou étrangers, des laboratoires publics ou privés. 
Endogenous Technology Adoption and Medical Costs

\section{RESEARCH CENTER \\ ESSEC Working Paper 1518}

2015

Karine Lamiraud

Stephane Lhuillery

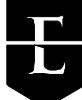




\title{
Endogenous Technology Adoption and Medical Costs
}

\author{
Karine Lamiraud ${ }^{1}$ \\ ESSEC Business School and THEMA-University of Cergy Pontoise, Paris, France \\ lamiraud@essec.edu
}

Stephane Lhuillery ${ }^{2}$

BETA (UMR-CNRS 7522) and ICN Business School, Nancy, France

stephane.lhuillery@icn-groupe.fr

Funding: Swiss National Science Foundation (Grant: 100014-122610)

No conflict of interest

1. Corresponding author. Department of Economics, ESSEC Business School, Avenue Bernard Hirsch, B.P. 50105, 95021 Cergy, France.

Other affiliation: THEMA-University of Cergy Pontoise, 33, boulevard du Port, 95011 Cergy-Pontoise Cedex, France.

Karine Lamiraud was an assistant Professor at the University of Lausanne when the research was initiated.

Email: lamiraud@essec.edu

Phone: (33) 629460225

2. Stephane Lhuillery was a researcher at EPFL Lausanne when the research was initiated. 


\begin{abstract}
Despite the claim that technology has been one of the most important drivers of healthcare spending growth over the past decades, technology variables are rarely introduced explicitly in cost equations. Furthermore, technology is often considered exogenous.

Using 1996-2007 panel data on Swiss geographical areas, we assessed the impact of technology availability on per capita healthcare costs covered by basic health insurance while controlling for the endogeneity of health technology availability variables. Our results suggest that medical research, patent intensity and the density of employees working in the medical device industry are influential factors for the adoption of technology and can be used as instruments for technology availability variables in the cost equation. Our results are similar to previous findings: CT and PET scanner adoption is associated with increased healthcare costs while increased availability of PTCA facilities is associated with reductions in per capita spending. Nevertheless, our results suggest that the magnitude of these relationships is much greater in absolute value than that suggested by previous studies which did not control for the possible endogeneity of the availability of technologies.
\end{abstract}

Keywords: healthcare costs, technology change, medical research 


\section{Introduction}

It is widely accepted that technological change is one of the most important drivers of healthcare spending growth (Fuchs, 1996). Newhouse (1992) suggests that in the five decades preceding $1990,50 \%$ of US healthcare growth was attributable to new technologies. Barros (1998) suggests that technological change may explain $30 \%$ of healthcare expenditure increases in OECD countries. Despite this, research measuring the influence of technology on rising healthcare costs is scarce (Okunade and Murthy, 2002; McGuire and Serra-Sastre, 2009). Few studies on costs have explicitly introduced technology variables (Chernew and Newhouse, 2012). Instead the focus is placed on new drugs (Lichtenberg, 2006; Cïvan and Köksal, 2010) perhaps because technological change is difficult to measure accurately.

This study aimed to investigate whether healthcare technology is an important explanatory factor in rising healthcare costs. Our methodological approach was to introduce genuine technology variables. Building on a previous study (Baker et al., 2003) we analyzed healthcare technology implementation and use by analyzing the availability of medical technologies, which are potentially important cost drivers as they are costly to implement and/or are used to treat patients with expensive conditions. More specifically, we examined the effects of infrastructure-intensive facilities associated with cardiac patient treatment (Percutaneous Transluminal Coronary Angioplasty - PTCA; Pacemaker) and diagnostic imaging (Computed Tomography - CT; Positron Emission Tomography - PET). We considered that digital imaging technology is a good proxy for health technology progress for the following reasons: digital imaging technology is pervasive to several medical fields, is likely to complement new non-imaging technologies and treatments (including drugs), is used intensively in the most expensive therapeutic areas (Dunn et al., 2012) (oncology, cardiology, 
neurology and orthopedics) and represents the fastest growing part of medical expenditures in the US (Mitchell et al., 2008).

Our research differs from previous work in three major ways. First, we assessed the impact of technology availability on per capita healthcare $\operatorname{costs}^{1}$ while controlling for the endogeneity of technology variables by investigating the factors associated with technology availability. Results suggest that medical research, patent intensity and employee density in the medical device industry are influential factors in technology adoption and can be used as instruments for technology availability variables in the cost equation. Second, we relied on a unique exhaustive Swiss dataset of available radiology devices, including devices operated in public hospitals, private hospitals and private practices. In contrast, most US studies are based on the number of hospitals and other locations (e.g. private practices or specialized clinics) reporting to have at least one of these devices, rather than the total number of devices used. Furthermore, our data cover a much longer time span than previous research. Results suggest that previous studies underestimated the magnitude of the relationship between technology availability and healthcare costs, and that this relationship is not the same across technologies. Whereas increased availability of CT and PET scanners is associated with increased healthcare costs, the opposite is observed for PTCA facilities.

Our research represents a significant contribution both to the literature assessing the impact of technology on healthcare expenditures and to that identifying the determinants of health technology adoption.

This paper is structured as follows: Section 2 surveys the economic literature on the impact of medical technology on healthcare costs. Section 3 reviews previous work studying the factors

\footnotetext{
${ }^{1}$ As explained below, healthcare costs considered in this article are utilization costs reimbursed by basic health insurance, plus out-of-pocket expenditures in basic health insurance
} 
associated with the diffusion of medical technologies. Section 4 presents data and methods, while Section 5 provides and discusses empirical results. A final section concludes.

\section{The impact of technology on costs: literature background}

The main theoretical mechanisms to date are described before outlining the empirical methods generally used to measure the impact of technologies on costs.

\section{$2.1 \quad$ Theoretical mechanisms}

The literature describes several mechanisms underlying the positive impact of technological change on healthcare expenditures. Two model types exist, one considering technological progress as exogenous, the other endogenous (Chernew and Newhouse, 2012).

The first model type investigates how market equilibrium changes as new technology is introduced. Technological progress may have supply-side effects (shifting the technology supply curve to the right or left, depending on whether the new technology engenders higher or lower unit costs) and demand-side effects. The latter reflects a "treatment expansion effect" whereby new technologies lead more people to be treated for disease (Cutler and McClellan, 2001). This may help explain how new healthcare technology with lower unit costs sometimes results in higher total healthcare expenditures (Cutler and Huckman, 2003). The other model type focusses on the process of technical innovation, in particular, modeling the relationship between technology change and medical expenditures through healthcare insurance (Weisbrod, 1991; Feldstein, 1977; Chandra and Skinner, 2012). On the one hand, new technologies increase demand for health insurance. On the other hand, increased insurance leads to higher utilization of new technologies and therefore creates incentives to innovate. Consequently, under this model type, long-term healthcare expenditure growth is a by-product of the interaction between innovation and insurance. 


\subsection{Empirical studies}

Residual estimates and technology proxies serve as measures of technological change when empirically assessing its impact on healthcare expenditures.

The residual estimates approach assesses the impact of easily observable cost drivers, including income per capita, population age distribution, physician density and extent of insurance coverage $\mathrm{e}^{2}$ on health care costs. It then attributes the portion of healthcare spending not accounted for to healthcare technology (Newhouse, 1992; Barros, 1998). One drawback with this approach is that the impact of technology may be overestimated if other factors are incorrectly specified.

To date, various proxies have been used in the technology proxies approach. Some studies have used insurance coverage as a proxy for medical technology (Peden and Freeland, 1998). Others have incorporated a linear time trend (Blomqvist and Carter, 1997) since technological change occurs over time. However, a trend variable may capture effects of various nonstationary variables, and its incorporation severely affects the parameter estimates of other explanatory variables, in particular income (Roberts, 1999). Furthermore, the linear nature may be inappropriate if medical technology innovation is not linear (Willemé and Dumont, 2014). Still other studies have used R\&D spending specific to healthcare (Okunade and Murthy, 2002) or non-commercial medical research (Peden and Freeland, 1995). One problem with this proxy type is that it approximates innovation inputs but not innovation diffusion (Kleinknecht et al., 2002).

In order to alleviate such shortcomings, a fourth set of proxy-based studies in the literature have used explicit measures of medical equipment, such as the percentage of hospitals with high-tech equipment or the availability of infrastructure-intensive facilities. These studies

\footnotetext{
${ }^{2}$ For a review of the literature on the determinants of per-capita health expenditures, see for example Gerdtham and Jönsson (2000).
} 
have reported a positive impact on total costs for PET scanners (Koenig et al., 2003; Baker et al., 2003), CT scanners (Baker et al., 2003; Baker et al, 2008), Magnetic Resonance Imaging (MRI) (Koenig et al., 2003, Baker et al., 2008), implantable cardioverter defibrillator facilities (Baker et al., 2003) and neonatal intensive care units (NICUs) (Baker et al., 2003), and a negative impact on costs for PTCA (Baker et al., 2003; Hearle et al., 2003). Non-significant results or inconsistent results have been found for single-photon emission computed tomography scanners (SPECT) (Koenig et al., 2003; Hearle et al., 2003) and radioisotope services (Hay et al, 2003; Hearle et al., 2003). Despite introducing genuine technology variables, this fourth set of studies share a major caveat with the others: technology is considered exogenous, even though theoretical literature suggests technology availability might in fact be endogenous.

Our paper contributes to this fourth set of proxy-based studies and builds on the theoretical literature dealing with endogeneity. We capture technology through genuine technology variables, contending that technology availability might be endogenous to the extent that unobserved factors may have an impact both on healthcare costs and on technology density in a given area. For example, it could be that areas which subscribe less to medical care (and place greater focus on promoting preventive behaviors) are more attracted to new technologies (especially those involving early diagnostic procedures). To understand the costs associated with introducing new medical technologies, an analysis of the factors associated with technology adoption is required (Gelijns and Rosenberg 1994).

\section{Developing the endogeneity view of medical technology adoption}

This section provides a review of the literature studying factors associated with technology adoption. To identify possible drivers of medical technology adoption, we focus on health economics literature complementing it with research in economics of innovation dealing with 
technology adoption in other fields. Determinants of technology adoption include adopter characteristics, the characteristics of medical device companies and the financing and geographic environments where technologies evolve.

\subsection{The characteristics of adopters (demand for medical technologies)}

Demand for medical technologies is driven by providers (physicians) and consumers (patients).

For providers, the adoption of new technologies is influenced by informed and influential individuals (Huckman and Pisano, 2006; Aarons et al., 2011). Adoption has been shown to depend on the positive influence of specialist physicians (Baker, 2001). However, learning capabilities - based primarily on research capabilities - are the main driver for the identification and utilization of external new technologies and knowledge. Three main factors explain the critical role of researchers in technology adoption: first, researchers are more likely to be aware of the latest inventions or technological changes through research networks (Spangenberg et al., 1990; Escarce, 1996; Bobrowski, 2000; Cutler and Kadiyala, 2003; Estabrooks et al., 2008; Angst et al., 2010). Second, as well as being adopters, researchers are producers of knowledge likely to be shared with device suppliers in order to convert their ideas into innovations. These specific technology users are thus kept up to date and even mollycoddled by device suppliers (Von Hippel and Finkelstein, 1979; Rosenberg, 1992; Riggs and Von Hippel, 1994; Heidenreich and McClellan, 2003; Lettl et al., 2006 ; Hyysalo, 2006 ; Chatterji et al., 2008). Finally, researchers have lower adoption costs because they are more accustomed to exploring and absorbing new technologies (Cohen and Levinthal, 1989; Åstebro, 2004). 
With respect to patients, previous research has highlighted the role of income and education in the diffusion of new technologies. GDP per capita is a major driver of the early adoption of medical technologies (Slade and Anderson, 2001). This has also been found at the micro level but with more mixed results (Cutler and McClellan, 1996; Baker, 2001). Other research has highlighted that people with higher educational levels are more likely to be aware of recent innovation in medical imaging devices and have easier access to related procedures (LlerasMuney and Lichtenberg, 2002).

\subsection{The supply of medical technologies}

With respect to the device industry, the presence of a local high-tech industry is considered influential in the adoption and diffusion of technologies. The adoption and performance of novel technologies usually involves important complementary assets (Teece, 1986; Milgrom and Roberts, 1990) such as high-tech equipment or intermediary goods and services. These include skilled employees (Barley, 1986; Schumacher, 2002; Dranove et al., 2012) (e.g. remote control information and communications technology (ICT) specialists for pacemakers), complementary high-tech equipment (e.g. computer-aided design software, robots, cardiac monitoring devices, etc.), intermediary goods (e.g. contrast agents for PET scanners), and services (Lee, 1992) (e.g. training, maintenance). In this respect, the presence of a local high-tech industry may foster adoption for two main reasons. First, a larger local market lowers the costs of complementary human resources and services. Second, a large number of experienced local human resources and invention capabilities increase availability of information and knowledge about new technologies.

\subsection{Financing and geographic environments}


Regarding healthcare financing, numerous empirical studies highlight faster adoption of new technologies in areas where insurance coverage is higher (Russell, 1979; Cutler and Sheiner, 1998). There is also evidence that a reduction in financial incentives for healthcare providers may slow the adoption of new technologies. For example, prospective payment systems (PPS) in hospital financing have been shown to delay the diffusion of cost-increasing technologies (Romeo et al., 1984). This is also true for MRI in HMO (Health Maintenance Organizations) programs in the American system (Baker, 2001), for angioplasty (Cutler and McClellan, 1996) and NICUs (Baker et al., 2002). However, other studies did not find any relationship between the HMO market share and technology diffusion (Hill and Wolfe, 1997).

Finally, geographic distance between healthcare providers can accelerate or hamper adoption strategies among healthcare units competing in the same health market. Acceleration arises from competition with already-equipped neighbors (competition behavior), while delays occur if patients can be transferred to already-equipped neighbors (cooperation behavior) (Cutler and McClellan, 1996).

Although the role of researchers and the existence of a local high-tech medical industry are common factors in the study of economics of innovation dealing with technology adoption in several fields, the present study is the first to test whether they are possible determinants of innovation adoption in the medical device sector. We also investigated whether these two variables could serve as instruments for technology availability in the healthcare cost equation. We expected them to have a direct impact on the adoption of new technology and an indirect impact on costs - through the availability of costly technology - as there is no reason why they should have a direct impact on expenditures reimbursed by basic insurance ${ }^{3}$.

\footnotetext{
${ }^{3}$ Research activities impact other sources of healthcare financing (i.e. public subsidies) and do not directly lead to higher healthcare utilization costs.
} 


\section{Methods and data}

We studied the impact of technology availability on costs, and the factors associated with healthcare technology availability. We built a longitudinal dataset for Switzerland ${ }^{4}$ using the period 1996-2007, information being reported at two levels: canton $(c)$ and year $(t)$. Our database comprised 312 observations. Tables 1 and 2 describe all variables and sources.

We modelled per capita expenditures on healthcare services (denoted $C_{c t}$ ) as follows:

$$
\log \left(C_{c t}\right)=\beta_{1} T_{c t}+\beta_{2} D_{c t}+\beta_{3} S_{c t}+\beta_{4} I_{c t}+\beta_{5} Y_{t}+c_{c}+\varepsilon_{c t}
$$

$C_{c t}$ included services covered by compulsory basic health insurance for adults over $25^{5}$.

$T_{c t}$ is a vector of four technology density variables, with $T_{c t}=\left(C T_{c t}, P E T_{c t}, P T C A_{c t}, P A C E_{c t}\right)^{6}$.

$D_{c t}$ included demand variables such as the population distribution by age, education level, unemployment rate and yearly per capita income.

$S_{c t}$ covers supply variables such the density of specialist physicians.

$I_{c t}$ captures Insurance variables: percentages of the population which opted for higher deductible options, for plans with limited choice of providers and a DRG variable ${ }^{7}$.

$Y_{t}$ included year dummies

\footnotetext{
${ }^{4}$ A brief summary of the Swiss system is available in Appendix 1

${ }^{5}$ Healthcare costs considered in this article represented $41 \%$ of the total healthcare costs in Switzerland in 2007. The other main sources of healthcare financing included expenses covered by voluntary supplementary health insurance $(9.2 \%)$, household direct contributions $(25 \%)$ through out-of-pocket payments for healthcare goods not included in the basic or supplementary benefit packages, and public subsidies to local facilities (16.2\%). The first two sources of healthcare financing were not considered for data availability reasons, the latter because it is not a good measure of healthcare costs generated by citizens. In particular, public subsidies include expenditure for prevention as well as support for research and teaching activities. Note that it is crucial not to consider this latter type of cost for the relevance of our proposed instruments.

${ }^{6}$ MRI was not included in the set of variables because information on MRI availability was not collected in medical practice settings by federal authorities. Note that $96.4 \%$ of hospital centers which were equipped with MRI were also equipped with CT scanners (source: authors' computations on Swiss hospital key figures published by Federal Office of Public Health, 2003 - 2012). Further research may consider to build an index of technology based on imaging devices.

${ }^{7}$ Switzerland progressively implemented a Diagnostic Related Group (DRG) payment system between 2002 and 2012
} 
Canton-fixed effects $\left(c_{c}\right)$ captured unobserved heterogeneity between cantons (e.g. cultural factors, inclination to use healthcare).

A canton fixed-effects linear model was estimated, thus controlling for the panel structure of the data. A key econometric issue is that the coefficient $\beta_{l}$ is likely to be biased if technology variables are endogenous.

Davidson-MacKinnon exogeneity tests were performed. The possible endogeneity of $T_{c t}$ variables was accounted for using an Instrument Variable (IV) approach. When the four technologies were introduced together in (1), at least four instruments were needed. To identify potential instruments (i.e. variables that are correlated with technology densities but which have no direct effect on healthcare costs and are thus excluded from the cost equation) for the technology density variables, we estimated a Tobit model based on the density of each technology. A Tobit model seemed the natural solution to account for the censored nature of our data. Zero values for technology density in a small number of cantons did not mean those cantons had zero willingness to pay for installations of technologies, but that their willingness to pay was lower than an "adoption threshold" (not observed). Thus, estimations were based on the latent variables $T_{c t}^{*}$ :

$$
\begin{aligned}
& T_{c t}^{*}=\gamma_{1} A_{c t}+\gamma_{2} M D_{c t}+\gamma_{3} F G_{c t}+\gamma_{4} Y_{t}+c_{c}+v_{c t} \\
& \text { with } \mathrm{T}_{c t}=\mathrm{T}_{c t}^{*} \text { if } \mathrm{T}_{c t}^{*}>0 \text { and } 0 \text { otherwise. }
\end{aligned}
$$

$A_{c t}$ is a vector of adopter's characteristics variables. In addition to the demand and supply variables described above, certain variables were specific to the technology adoption 
equations. The role of research was estimated using the density of medical publications computed for the four most costly medical fields (cardiology, oncology, neurology, orthopedics) (Dunn et al., 2012) and for radiology (Appendix 2). These are the research fields most likely to influence the adoption of the four technologies under investigation.

Regarding the characteristics of medical device companies included in $M D_{c t}$, the presence of a local high tech industry was captured using locally experienced human resources (employee density in the medical device industry) and inventive capabilities (patent intensity) (Appendix 2).

$F G_{c t}$ refers to financing and geographic variables. To capture potential spatial interactions, we computed a weighted index of devices installed in other cantons (Appendix 2). Regarding the financing environment, we used the insurance variables described above.

Research, skilled human resources, patent densities and neighbour variables were lagged in the regressions to mitigate potential endogeneity problems.

We formally tested the validity of our potential instruments. Three tests were performed.

First, in order to rule out any direct effect of the potential instruments on the cost variable, we ran the cost equation (1) including potential instruments as covariates. Second, we performed a Sargan test in order to test the assumption that instruments were uncorrelated with $\varepsilon_{c t}$. Third, in order to test for the strength of our instruments, we computed from the first-stage regressions (i.e. equations 2) F-statistics of a joint test whether all excluded instruments were significant (Staiger and Stock, 1997).

\section{$5 \quad$ Results}

\subsection{Descriptive results}

Figure 1, which displays mean monthly per capita healthcare expenditures in each canton in 2007, shows the huge inter-canton variability in healthcare costs. Per capita expenditures 
ranged from $187\left(\mathrm{AI}^{8}\right)$ to $376(\mathrm{BS})$ Swiss Francs. Figure 1 also displays each canton's healthcare expenditure evolution between 1996 and 2007. Cantons with low levels of healthcare expenditures exhibited higher growth rates, suggesting a catch-up phenomenon.

CT and PET scanner densities rose sharply over time. CT scanners arrived in Switzerland in 1988, with the first 5 being installed in 3 cantons (AG, BE, ZH). In late 1997, $172 \mathrm{CT}$ scanners were operating in Switzerland in 23 cantons. By late 2007, this number had increased to 227 in 24 cantons. Over this 20-year period, $611 \mathrm{CT}$ scanners were installed in Switzerland $^{9}$. The mean operating time was 5.5 years during this period. PET scanner diffusion has been slower. In 1996, 3 PET scanners were in operation. In 2007, this number was 17 provided in only 10 cantons. In 2007 CT and PET scanner density varied substantially between cantons (Figure 2). The four most expensive cantons (BS, GE, TI, VD) were well equipped with both technologies. Furthermore, of the 10 cantons with the lowest per capita health costs, only 2 were equipped with PET facilities.

The number of centers with PTCA facilities rose by 55\% between 1996 and 2007, from 18 to 28 centers, in 10 and 13 cantons, respectively. The number of centers with pacemaker capabilities remained quite stable from 1996 to 2007 with 64 and 69 centers in 22 and 23 cantons, respectively. Only 3 cantons were not equipped with pacemaker facilities in 2007 . Figure 3 displays the PTCA and pacemaker facility densities across cantons in 2007. BS, GE and VD were the best equipped with PTCA facilities. However, other cantons with high healthcare costs such as JU, NE, BL and SH did not offer any PTCA facilities. Furthermore, SG, LU, GR, TG, AG and VS, which exhibited low/average healthcare costs, were well

\footnotetext{
${ }^{8}$ See Table 3 for the meaning of abbreviations of Swiss cantons

${ }^{9}$ Note that CT scanner adoption is reversible. Some hospitals and medical practices were equipped at some point but were no longer equipped a couple of years later.
} 
equipped with PTCA facilities. A mixed pattern was also found for pacemakers, with high densities in cantons with high (e.g. JU, NE) and low (e.g. UR, AR) healthcare expenditures.

Table 3 displays the average values for publication, patent and medical device employee densities over 1996-2007 in each canton. Cantons with university hospitals (BS, GE, VD, ZH, BE) came first for publication densities. However, research activity was also found in cantons with no research hospitals. Furthermore, many cantons in Switzerland had a patenting medical device industry. ZG, SH and SO were the most invention-intensive. These three cantons also exhibited the highest densities of employees working in the medical device industry.

\subsection{The determinants of technology adoption}

As the equations studying factors associated with technology diffusion aim to identify potential instruments for technology density, we will first comment on the analyses of the determinants of technology adoption. The econometric results are displayed in Table 4 (CT and PET scanner densities) and Table 5 (densities in PTCA and pacemaker facilities). For each technological device, columns (1) to (6) in Tables 4 and 5 display results when the various research fields investigated are introduced one by one before being introduced altogether in column (7).

According to columns 1-5 in Tables 4 and 5, intensive research in cardiology, oncology, neurology, radiology and orthopedics was a significant driver of CT scanner and PTCA densities. Research in neurology, radiology and orthopedics was significantly associated with the adoption of PET scanners. Research in cardiology, oncology and radiology was significantly associated with increased densities in pacemaker facilities. For each 
technological device, the intensity of publications (all fields) was also positively influential (column 6).

The positive influence of publications in various fields variables remained but their significance was reduced when introduced simultaneously (columns 7 in Tables 4 and 5). A Wald test confirmed that we could not reject the assumption that the five coefficients were jointly different from zero, thereby confirming the role of various academic activities on the adoption of new medical technologies.

In line with previous research, specialist physician density had a positive, significant impact on the four technologies. The percentage of over-65's had a positive influence on CT, PET scanner and PTCA availability. This population boosted the installation of new devices, suggesting its contribution to technological change. The results for other socio-demographic variables were reasonably consistent with the literature: per capita income was positively associated with technology densities. This was significant for PTCA and pacemaker facilities, less significant for PET scanner densities. A higher unemployment rate was significantly negatively associated with CT and PTCA densities. Cantons with a higher percentage of lesseducated inhabitants were less equipped but this was only statistically significant for PET scanners.

Concerning variables of the MD vector, the density of patents in medical devices had a significant positive impact on CT scanner density. The density of people working in the medical instrument industry had a positive influence both on CT scanner and pacemaker facility installations. These results support the hypothesis that both local invention capabilities and technician availability are important in the adoption of large medical devices, especially CT scanners. Only the density of people working in the medical instrument industry influenced the density of pacemaker facilities. This supports the interpretation that the number 
of available local technicians matters but that the skill level required for pacemakers is lower than for more recent technologies. Despite widespread availability and continuous improvement, pacemaker technology, unlike CT scanner technology, does not require invention skills. None of the effects mentioned above was found for PET scanners or PTCA.

Spatial market interactions were negative for CT scanners, PTCA and pacemakers, suggesting cooperation rather than competition between cantons, but associated coefficients were not significant. Conversely, the coefficient was significant and positive for PET scanners, suggesting competition. Regarding financing variables, there was no significant relationship between the proportion of HMO subscribers and CT/PET scanner density. These findings contrast with previous US -based results. However, Swiss HMOs are not directly comparable with their US counterparts, as they are mostly restricted to outpatient practices and do not include hospital facilities. Accordingly, there is no incentive to reduce hospital costs or slow the adoption of new technologies in hospitals. Our results are not surprising given that the majority of CT (70\% in 2007) and PET (76\% in 2007) scanners were operating in hospitals. Areas with a higher proportion of HMO subscribers were associated with a higher density of PTCA and pacemaker facilities. This can be interpreted in the light of the results on costs (see next section). HMOs boosted the introduction of equipment which reduces costs (PTCA). In this respect, HMOs may be expected to reduce healthcare costs.

A higher percentage of insurance policyholders with high deductibles was not significantly associated with the diffusion of technologies. Unlike other studies, we did not find that the higher the extent of insurance coverage the higher the density in technology (Russell, 1979). This may be explained by the fact that the Swiss population benefits from wide insurance coverage in all plans, including those with the highest deductibles. 
The DRG payment variable was not associated with any technology densities and was therefore dropped from regressions. This may be because our dataset does not cover the full period during which DRG payment system was implemented.

Our analysis of technology adoption enabled us to identify variables associated with technology variables and thus which might serve as instruments for technology variables in the cost equation: CARDIOLOGY, ONCOLOGY, NEUROLOGY, RADIOLOGY, ORTHOPEDICS, EMPLOYEES, PATENT and NEIGHBOUR ${ }^{10}$. As explained above, there is no reason why research activity, which is financed through other financing sources, might have a direct impact on health care utilization costs reimbursed by basic insurance. Neither were the density of employees working in medical instrument manufacturing industries and patent intensity (which approximates the importance of inventors in the field of medical devices) expected to directly impact health care costs, as manufacturing employees and inventors do not carry out medical examinations but facilitate the availability of devices for physicians. The fact that all instrument variables were not significant when introduced together into the cost equation $(\mathrm{p}=$ $0.621)^{11}$ confirmed this. Each instrument variable was also individually introduced into the cost equation. None was significantly associated with healthcare costs (Appendix 3). Furthermore, a Sargan test led to the non-rejection of the null hypothesis that these instruments are uncorrelated with $\varepsilon_{c t}(\mathrm{p}=0.810)^{12}$. Furthermore, F-statistics from the first stage regressions show that $\mathrm{F}>10$ (columns 2-5 in Table 6), suggesting that our instruments meet Staiger and Stock's (1997) strong instrument criteria. Altogether these results suggest that our instruments are valid.

\footnotetext{
${ }^{10}$ NEIGHBOR is more a control variable and will technically serve as an instrument

${ }^{11}$ Joint test that all coefficients are zero

${ }^{12}$ The Sargan Test was performed on specification 6 (Table 6). This result is important because it rules out the possibility that our instruments could have been correlated with technologies not captured by our technology variables (e.g. availability of certain drug technologies).
} 


\subsection{The impact of technology on costs}

Table 6 reports the analyses examining the relationship between availability of the technologies considered and healthcare expenditure. Estimations in column 1 treated technology availability measures as exogenous. Columns 2 to 6 controlled for the endogeneity of technology availability variables using the IV method, one technology being introduced at a time (columns 2-5), all four being introduced in column 6.

The general pattern in our results is that greater CT and PET scanner availability were associated with higher per capita healthcare costs. Conversely, increases in the availability of PTCA facilities were associated with reductions in per capita healthcare costs. Finally, the density of pacemaker capabilities was not significantly associated with per capita healthcare expenditures. There are several possible explanations for these results. Although increased availability may directly result in greater diffusion for some technologies, for others, healthcare utilization may be relatively fixed, irrespective of increased availability. For example, it might be easier to increment diagnostic imaging procedures than cardiac procedures. The negative coefficient for PTCA may also suggest that the use of this technology tends to reduce the use of other medical services (for example by preventing further complications or reducing admissions). The fact that pacemaker technology is old might explain its non-significance. The general pattern in our results confirms Baker et al.'s (2003) findings.

One important result is that the magnitude of the relationship between technology availability and healthcare costs was much stronger when we controlled for the endogeneity of the availability of technologies (columns 2-6). The Davidson-MacKinnon's tests reported in Table 6 rejected the null hypothesis that technology variables were exogenous. We found that the magnitude of the coefficients for PET and CT scanners was twice as big when controlling for 
the endogeneity of the technology variable (comparing column 6 with column 1). The endogeneity bias was even stronger for PTCA with the absolute value coefficient of this technology being almost five times larger when controlling for endogeneity (comparing column 6 with column 1). In column 7, for robustness purposes, the cost equation was estimated simultaneously with the four technology equations using 3SLS.The results are very similar to those of the IV specifications including all four technologies (column 6), confirming the importance of the downward bias, in absolute value, characterizing results that did not control for endogeneity ${ }^{13}$.

However, our results suggest that possible mechanisms underlying CT/PET and PTCA endogeneity may be different. The increase in the coefficient for CT and PET would suggest that areas which subscribe less to medical care (and place greater focus on promoting preventive behaviors) are more attracted to implementing CT and PET devices. Patients in these areas would value diagnostic devices or consider such imaging technology more as an insurance in case of health problems. Regarding the increase of the absolute value of the coefficient for PTCA, it could be that areas that have strong preferences for healthcare are more attracted to treatment solutions such as PTCA facilities. The demand for treatment solutions would therefore drive both technology adoption and healthcare spending.

In addition to reinforcing previous assessments about the importance of technological change on healthcare costs, the instruments we identified to control for the endogeneity of technology variables also shed some light on the mechanisms through which some areas are more equipped in expensive technologies and thus may exhibit higher healthcare costs. In particular, intensive medical research or the presence of a local medical high-tech industry may lead to higher densities in medical technology and higher healthcare costs. The

\footnotetext{
${ }^{13}$ Per capita expenditures were also known for outpatient $\left(C_{c t}^{o}\right)$ and inpatient care $\left(C_{c t}^{i}\right)$ Results were not qualitatively different when run on outpatient and inpatient health care costs.
} 
importance of medical research as a driver for technology adoption also suggests that costly medical devices are not only adopted for treatment reasons but may be installed for medical research. This creates another source of benefit associated with new technologies. However, intensive medical research and the presence of a medical high-tech industry do not systematically lead to increased healthcare costs (e.g. pacemakers and PTCA).

With respect to other control variables in the cost equation, a higher income level was not significantly associated with higher healthcare expenditures. This result is consistent with others on Swiss data (Crivelli et al., 2006). Neither was a higher unemployment rate associated with healthcare expenditures. In contrast, a higher density of specialist physicians was associated with higher healthcare costs. This is not surprising in a fee-for-service system and may suggest a potential supply-induced demand problem (Crivelli et al, 2006; Reich et al., 2012). A higher percentage of elderly people in the Swiss population was not significantly associated with healthcare costs, although it did have an indirect impact through the availability of devices (positive for CT and PET density, negative for PTCA density). A higher percentage of less-educated people was associated with reduced healthcare costs. The percentage of enrollees with high deductible health plans was not significantly associated with healthcare costs. This suggests that the introduction of deductibles in Switzerland did not help solve the moral hazard problem (Schellhorn, 2001). Areas with a higher percentage of enrollees in HMO-type plans had lower healthcare expenditures. This is consistent with Reich et al. (2012). The DRG variable was not significant and was dropped from regressions.

\section{Conclusion}

Our study investigated the direction and magnitude of the relationship between selected technologies and healthcare costs and is, to our knowledge, the first to control for the possible 
endogeneity of technological availability. Our results suggest that increased availability of CT and PET devices is associated with increased healthcare costs. The opposite relationship is observed for PTCA facilities. This is consistent with studies which, unlike ours, did not account for the endogeneity of the supply of technologies. However, the magnitude of these relationships in our study is much bigger in absolute value. We show that the bias associated with endogeneity is substantial and thus strongly reduces the actual impact of technology on costs. Our results highlight that medical research, patent intensity and the local availability of a skilled labor force working in the medical device industry facilitate the adoption of medical technology and can be used as valid instruments for technology availability in the cost equation. In this respect, our work contributes significantly both to the literature assessing the impact of technology on healthcare expenditures, and to that identifying the determinants of health technology adoption, shedding light on the mechanism through which certain geographic areas are more equipped in expensive technologies than others and thus may exhibit higher health care costs.

Although a selected number of technologies can only partially capture the overall level of technology availability in a geographic area, our paper is an important contribution to the literature, given that it is one of the first to look at the relationship between technological change and health care costs outside the US. Furthermore, the proposed methodology to account for the possible endogeneity of technology availability can be easily applied to the understanding of health care costs variability within any given country or between two or more countries, as publicly available datasets, PATSTAT and SCOPUS, were used to compute patent intensity and research intensity, respectively. 
Overall, our results question whether it is appropriate to point the finger at those cantons with higher healthcare costs. Since expensive cantons may also be the ones with intensive medical research, they are the cantons contributing most to future treatments which in time will become available to all cantons. In this respect, these results remind us of the necessity to assess the benefits associated with new medical technologies in a global and dynamic fashion. 


\section{References}

Aarons, G.A., Hurlburt, M., Horwitz, S.M., 2011. Advancing a conceptual model of evidencebased practice implementation in public service sectors. Administration and Policy in Mental Health and Mental Health Services Research 38(1), 4-23.

Angst, C.M., Agarwal, R., Sambamurthy, V., Kelley K., 2010. Social contagion and information technology diffusion: the adoption of electronic medical records in US hospitals. Management Science 56(8), 1219-1241.

Åstebro, T., 2004. Sunk Costs and the Depth and Probability of Technology Adoption. Journal of Industrial Economics 52(3), 381-399.

Baker, L.C., Atlas, S., Afendulis, C., 2008. Expanded use of Imaging Technology and the Challenge of Measuring Value. Health Affairs 27(6), 1467-1478.

Baker, L.C., Birnbaum, H., Geppert, J., Mishol, D., Moyneur, E., 2003. The relationship between technology availability and healthcare spending. Health Affairs Web Exclusive W3:537-W3:551

Baker, L.C., Ciaran, S., Phibb, C.S., 2002. Managed Care, Technology Adoption, and Health Care: The Adoption of Neonatal Intensive Care. Rand Journal of Economics 33(3), 524-548.

Baker, L.C., 2001. Managed care and technology adoption in health care: Evidence from Magnetic Resonance Imaging. Journal of Health Economics 20(3), 395-421.

Barley, S.R., 1986. Technology as an occasion for structuring: Evidence from Observations of CT scanners and Social Order of Radiology Departments. Administrative Science Quarterly 31(1), 78-108.

Barros, P.P., 1998. The Black Box of Healthcare Expenditure Growth Determinants. Health Economics 7, 533-544.

Blomqvist,A.G., Carter, R.A., 1997. Is Healthcare Really a luxury? Journal of Health Economics 16, 207-229.

Bobrowski, P.E., 2000. A Framework for Integrating External Information into New Product Development: Lessons from the Medical Technology Industry. The Journal of Technology Transfer 25(2), 181-192.

Chandra, A., Skinner, J., 2012. Technology Growth and Expenditure Growth in Health Care. Journal of Economic Literature 50(3), 645-680.

Chatterji, A.K., Fabrizio, K.R., Mitchell, W., Schulman, K.A., 2008. Cooperation In The Medical Device Industry: When physician-inventors team up with industry, is it collaborative innovation or conflict of interest? Health Affairs 27(6), 1532-1543.

Chernew, M.E., Newhouse, J.P., 2012. Healthcare Spending Growth. In Handbook of Health Economics, Pauly MV, McGuire TG, Pedro PB (eds). Elsevier, 1-43.

Civan, A., Koksal, B., 2010. The effect of newer drugs on health spending: do they really increase the costs? Health Economics 19(5), 581-595.

Cohen, W.M., Levinthal, D.A., 1989. Innovation and Learning: The Two Faces of R\&D. The Economic Journal 99(397), 569-596.

Crivelli, L., Filippini, M., Mosca I., 2006. Federalism and regional healthcare expenditures: an empirical analysis for the Swiss cantons. Health Economics Letters 15, 535541.

Cutler, D.M., Huckman, R.S., 2003. Technological development and medical productivity: the diffusion of angioplasty in New York State. Journal of Health Economics 22(2), 187-217.

Cutler, D.M., Kadiyala, S., 2003. The Return to Biomedical Research: Treatment and Behavioral Effect. In Measuring the Gains from Medical Research: An Economic 
Approach, Murphy KM, Topple RH (eds). The University of Chicago Press, 110 162.

Cutler, D.M., McClellan, M., 1996. The Determinants of Technological Change in Heart Attack Treatment. NBER Working Paper 5751.

Cutler, D.M., McClellan, M., 2001. Is Technological Change In Medicine Worth It? Health Affairs 20(5),11-29.

Cutler, D.M., Sheiner, L., 1998. Managed Care and the Growth of Medical Expenditures. In Frontiers of Health Policy Research, Garber AM (ed). The MIT Press: Cambridge, Mass.

Dranove, D., Forman, C., Goldfarb, A., Greenstein, S., 2012. The Trillion Dollar Conundrum: Complementarities and Health Information Technology. NBER Working Paper 18281.

Dunn, A., Liebman, E., Shapiro, A.H., 2012. Decomposing Medical-Care Expenditure Growth. Reserve Bank of San Francisco Working Paper 2012-26.

Estabrooks, C.A., Norton, P., Birdsell, J.M., Newton, M.S., Adewale, A.J., Thornley, R. 2008. Knowledge translation and research careers: Mode I and Mode II activity among health researchers. Research Policy 37(6-7),1066-107.

Escarce, J.J. 1996. Externalities in hospitals and physician adoption of a new surgical technology: an exploratory analysis. Journal of Health Economics 15(6), 715-734.

Feldstein, M., 1977. Quality Change and the Demand for Hospital Care. Econometrica 45(7): 1681-1702.

Figlio, D.N., Kolpin, V.W., Reid, W.E., 1999. Do States Play Welfare Games? Journal of Urban Economics 46, 437-454

Fuchs, V., 1996. Economics, Values, and Healthcare Reform. American Economic Review 86 (1), 1-24.

Gelijns, A.C., Rosenberg. N., 1994. The dynamics of Technological Change in Medicine. Health Affairs 13(3), 28-46.

Gerdtham, U.G., Jönsson, B. 2000. International comparisons of health expenditure: theory, data and econometric analysis. In Handbook of Health Economics, Culyer AJ Newhouse JP (eds). Elsevier, 1, 11-53.

Hay, J.W. , 2003. Hospital Cost Drivers: an evaluation of 1998 - 2001 State-Level Data. The American Journal of Managed Care 9(1), 13-24.

Hearle, K., Koenig, L., Rudowitz, R., Siegel, J.M., Dobson, A., Ho, S., 2003. Drivers of Expenditure Growth in Outpatient Care Services. American Journal of Managed Care 9 (1), SP25-SP33

Heidenreich, P., McClellan, M.B., 2003. Biomedical Research and Then Some: the Causes of Technological Change in Heart Attack Care. In The Value of Biomedical Research, Murphy K, Topel RH (eds). University of Chicago Press: Chicago, 163-205.

Hill, S.C., Wolfe, B.L., 1997. Testing the HMO competitive strategy: An analysis of its impact on medical care resources. Journal of Health Economics 16(3),261-286.

Huckman, R.S., Pisano, G.P., 2006. The firm specificity of individual performance: Evidence from cardiac surgery. Management Science 52(4),473-488.

Hyysalo, S. 2006. The Role of Learning-by-Using in the Design of Healthcare Technologies: A Case Study. The Information Society: An International Journal 22(2),89-99.

Kleinknecht, A., Van Montfort, K., Brouwner, E., 2002. The Non-Trivial Choice between Innnovation Indicators. Economics of Innovation and New Technology 11(2), 109-121. 
Koening, L., Siegel, J., Dobson, A., Hearle, K., Ho, S., Rudowitz, R., 2003. Drivers of Healthcare Expenditures Associated with Physician Services. American Journal of Managed Care 9(1), 34-42.

Lee, D.W. ,1992. Estimating the effect of new technology on Medicare Part B expenditure and volume growth: Do related procedures matter? Advances in Health Economics and Health Services Research 13, 43-64.

Lettl, C., Herstatt, C., Gemuenden, H.G., 2006. Users'contributions to radical innovation: Evidence from four cases in the field of medical equipment technology. R\&D Management 36(3),251-272.

Lichtenberg, F.R., 2006. The effect of using newer drugs on admissions of elderly Americans to hospitals and nursing homes: state-level evidence from 1997 to 2003. Pharmaco Economics 24(3), 5-25.

Lleras-Muney, A., Lichtenberg, F., 2002. The Effect of Education on Medical Technology Adoption: Are the More Educated More Likely to Use New Drugs. NBER Working Paper 9185.

Maeder, M., Stauffer, J.C., Windecker, S., Eberli, F., Pedrazzini, G., Vuilliomenet, A., et al., 2006. Interventional cardiology in Switzerland 2004. Kardiovaskuläre Medizin 9, 213-26.

Maeder, M.T., Stauffer, J.C., Windecker, S., Pedrazzini, G., Kaiser, C.A., Roffi, M., et al., 2008. Interventional cardiology in Switzerland during the year 2006. Kardiovaskuläre Medizin 11, 187-95.

Maeder, M.T., Stauffer, J.C., Windecker, S., Pedrazzini, G., Vuilliomenet, A., Rickli, H., 2007. Interventional cardiology in Switzerland during the year 2005. Kardiovaskuläre Medizin 10, 92-100.

Maeder, M.T., Stauffer, J.C., Windecker, S., Roffi, M., Kaiser, C.A., Stauffer, J.C., Pedrazzini, G., Ricki, H., 2010. Interventional cardiology in Switzerland during the year 2007. Kardiovaskuläre Medizin 13(1), 18-24.

McGuire, A., Serra-Sastre, V., 2009. What do we know about the role of healthcare technology in driving healthcare expenditure growth? In The economics of new health technologies: incentives, organization, and financing, Costa-i-Font J, Courbage C, McGuire A (eds.). Oxford University Press: Oxford, 3-18.

Milgrom, P., Roberts, J. 1990. The economics of modern manufacturing: Technology, strategy, and organization. American Economic Review 80(3), 511-528.

Mitchell JM. Utilization Trends for Advanced Imaging Procedures. Evidence From Individuals With Private Insurance Coverage in California. Medical Care 2008; 46(5):460-466.

Newhouse, J.P., 1992. Medical Care Costs: How Much Welfare Loss? Journal of Economic Perspectives 6(3), 3-21

Okunade, A.A., Murthy, V.N.R., 2002. Technology as a major driver of healthcare costs: a cointegration analysis of the Newhouse conjecture. Journal of Health Economics $21,147-159$.

Peden, E.A., Freeland, M.S., 1995. A Historical Analysis of Medical Spending Growth, 1960 - 1993. Health Affairs 14(2), 235-247.

Peden, E.A., Freeland, M.S., 1998. Insurance Effects on US Medical Spending (1960 - 1993). Health Economics 7, 671-687.

Pedrazzini, G. , 1998. Heart interventions in Switzerland 1996. Schweiz Rundsch Med Prax 87,821.4-826.31.

Reich, O., Weins, C., Schusterschitz, C., Thöni, M., 2012. Exploring the disparities of regional healthcare expenditures in Switzerland: some empirical evidence. European Journal of Health Economics 13(2), 193-202. 
Riggs, W., Von Hippel, E., 1994. Incentives to innovate and the sources of innovation: The case of scientific instruments. Research policy 23(4), 459-469.

Roberts, J., 1999. Sensitivity of elasticity estimates for OECD healthcare spending: analysis of a dynamic heterogeneous data field. Health Economics 8, 459-472.

Roffi, M., 1999. Herzeingriffe in der Schweiz 1997. Kardiovaskuläre Medizin 2, 302-18.

Roffi, M., 2000. Herzeingriffe in der Schweiz 1998. Kardiovaskuläre Medizin 3, 89-103.

Romeo, A.A., Wagner, J.L., Robert, H.L., 1984. Prospective reimbursement and the diffusion of new technologies in hospitals. Journal of Health Economics 3(1),1-24.

Rosenberg, N., 1992. Scientific instrumentation and university research. Research Policy 21(4), 381-390.

Russell, L.B., 1979. Technology in Hospitals. Brooking Institute, Washington DC, USA.

Schellhorn, M., 2001. The effect of variable health insurance deductibles on the demand for physician visits. Health Economics 10(5), 441-456.

Schlüter, L., Rickli, H., Vuillomenet, A., Chatelain, P., Eberli, F., Meier, B., et al., 2004. Interventions cardiaques percutanées en Suisse en 2001. Kardiovaskuläre Medizin 7, 61-70.

Schumacher, E.J., 2002. Technology, skills, and health care labor markets. Journal of Labor Research 23 (3), 397-415.

Shroder, M., 1995. Games the states don't play: Welfare benefits and the theory of fiscal federalism. The Review of Economics and Statistics 77 (1), 183-191.

Slade, E.P., Anderson, G.F., 2001. The relationship between per capita income and diffusion of medical technologies. Health policy 58(1),1-14.

Spangenberg, J.F., Starmans, R., Bally, Y.W., Breemhaar, B., Nijhuis, F.J., 1990. Prediction of scientific performance in clinical medicine. Research Policy 19(3),239-255.

Staiger, D., Stock, J.H., 1997. Instrumental variables regression with weak instruments. Econometrica 65, 557-586.

Teece, D.J., 1986. Profiting from technological innovation: Implications for integration, collaboration, licensing and public policy. Research Policy 15(6), 285-305.

Togni, M., Meier, B., 2002. Herzeingriffe in der Schweiz 2000. Kardiovaskuläre Medizin 5, 238-48.

Von Hippel, E., Finkelstein, S.N., 1979. Analysis of Innovation in Automated Clinical Chemistry Analyzers. Science \& Public Policy 6(1),24-37.

Wahl, A. 2001. Herzeingriffe in der Schweiz 1999. Kardiovaskuläre Medizin 4,268-81.

Weisbrod, B.A., 1991. The Healthcare Quadrilemma: An Essay on Technological Change, Insurance, Quality of Care, and Cost Containment. Journal of Economic Literature 29(2), 523-52.

Willemé, P., Dumont, M., 2014. Machines that go "ping": medical technology and health expenditures in OECD countries. Health Economics (published ahead of print). 


\section{Appendix 1: The Swiss health insurance system}

Switzerland (population 7.8 million in 2009) is divided into 26 geographic areas (cantons), with each canton responsible for the organization of its own healthcare system. The basic health insurance system is regulated by the Federal Law on Social Health Insurance (LAMal).

Basic health insurance is obligatory in Switzerland and a standardized benefit package is defined by law. However the extent of coverage varies as policyholders may choose between contracts with a low deductible level (300 CHF) (41.6\% of enrollees in 2007), a higher deductible level (500,1000, 1500, 2000 or $2500 \mathrm{CHF}$ ) (34\% of enrollees in 2007), and contracts with limited choice of providers (HMO-style contracts) (24.3 percent of enrollees in 2007). This latter figure reflects HMOs recently increasing market share, given that only $8.2 \%$ of enrollees held HMO-contracts in 2003. Physicians are paid on a fee-for-service basis except for physicians who provide services within HMO-contracts (paid on a per-capita basis).

Cost-sharing arrangements in basic insurance

All contracts include a deductible on yearly expenditures. Once the deductible level has been reached, enrollees pay a $10 \%$ co-insurance rate up to a maximum of $700 \mathrm{CHF}$. Hence, if the enrollee chooses a $300 \mathrm{CHF}$ deductible, then the maximum out-of-pocket amount that he or she may have to pay is $1000 \mathrm{CHF}$. 


\section{Appendix 2: Computation methods for the number of publications, employees working in the medical device industry, patents and for spatial interactions}

\section{Number of publications}

We computed the annual number of publications in medical fields including at least one author with a Swiss affiliation. Only publications of articles, editorials and letters in journals listed in Scopus over 1995-2006 were taken into account. The cantonal count was weighted and computed as the number of authors affiliated in a given canton divided by the number of authors affiliated with Swiss institutions. For example, an article with 2 authors from a Bern institute, 1 author from a Geneva institute and 2 non-Swiss authors associated with 2 nonSwiss institutes will lead us to credit the Bern and Geneva Cantons respectively of $2 / 3$ and $1 / 3$ publications. Similarly, we computed the number of academic publications in five specific medical fields (cardiology, oncology, neurology, radiology, orthopedics)

\section{Number of employees working in the medical device industry}

The total number of employees working in the medical device industry was computed, using the ISIC classification (NOGA in Switzerland) at the three digit level, as the sum of employees in two industries, the ISIC 266 industry that is the manufacture of irradiation, electromedical and electrotherapeutic equipments, and the ISIC 325 industry which is the manufacture of medical and dental instruments and supplies. Hospitals and medical laboratories can find skilled technicians in these two industries. The number of employees in these industries were available only for 1995, 2001, 2005 and 2008. The annual values were approximated taking the nearest year into consideration.

\section{Number of patents}

The patents considered in this study are those including applicants or inventors who provided an address in Switzerland and belonged to the A61B subclass in the IPC classification filed between 1992 and 2006. This IPC subclass covers instruments, implements, and processes for diagnostic, surgical and person-identification purposes, including obstetrics, instruments for cutting corns, vaccination instruments, finger-printing and psycho-physical tests. The year considered for invention is the earliest priority date (filing). The number of patents was calculated at the canton level according to the NUTS3 classification taken from the REGPAT database (OECD, 2008).

\section{Spatial interactions}

Following Shroder (1995) and Figlio et al. (1999), we used the inter-canton hospital patient mobility data in order to weight the competing offers of other cantons where patients can be treated $^{14}$. The weight is the fraction of patients who went to (an)other canton(s) to be treated: canton $i$ assigns each other canton $j$ a weight of $w_{i j}=$ patients $_{i j} / \sum_{\substack{j=1 \\ j \neq i}}^{26}$ patients $_{i j}$ where patient $s_{i j}$ is the number of patients of canton $i$ going to be cured in canton $j . w_{i j}$ is thus the share of patient of canton $i$ that is treated in canton $j$ out of the total number of patients treated outside canton $i$, in one of the other 25 cantons. Canton $i$ is assigned a weight of zero $\left(w_{i}=\right.$

\footnotetext{
${ }^{14}$ Insured people may choose to be treated at any hospital or at any physician's practice and therefore may be treated in cantons other than the one where they live. However, there are restrictions on reimbursement by basic insurance for inpatient care received outside the canton of residence or for outpatient care received outside the canton where policyholders live or work. An individual will be reimbursed only up to the amount that would have been charged in his/her canton of residence. If it is imperative to receive outpatient care outside the canton in which the individual lives or works, e.g. in an emergency or because he/she requires special treatment, health insurance will cover all the costs.
} 
0 ), and all weights sum to 1 . The weight is then multiplied by the technology density in each canton, to provide a composite indicator of neighboring competitors in each technology for each canton $i$. For example, for CT scanners, for each canton $i$ we generated the variable NEIGHBOUR $R_{j}^{C T}=\sum_{j \neq i} w_{i j}$ Density $_{j}^{C T}$. The NEIGHBOUR variable was computed in a similar way for the three other technologies. 
Appendix 3: Relationship between instrument variables and insurance medical costs

\begin{tabular}{|c|c|c|c|c|c|c|c|c|c|c|c|}
\hline & $\begin{array}{c}(1) \\
\text { GLS } \\
\text { coef/t }\end{array}$ & $\begin{array}{c}(2) \\
\text { GLS } \\
\text { coef/t }\end{array}$ & $\begin{array}{c}(3) \\
\text { GLS } \\
\text { coef/t }\end{array}$ & $\begin{array}{c}(4) \\
\text { GLS } \\
\text { coef/t }\end{array}$ & $\begin{array}{c}(5) \\
\text { GLS } \\
\text { coef/t }\end{array}$ & $\begin{array}{c}(6) \\
\text { GLS } \\
\text { coef/t }\end{array}$ & $\begin{array}{c}(7) \\
\text { GLS } \\
\text { coef/t }\end{array}$ & $\begin{array}{c}(8) \\
\text { GLS } \\
\text { coef/t }\end{array}$ & $\begin{array}{c}(9) \\
\text { GLS } \\
\text { coef/t }\end{array}$ & $\begin{array}{c}(10) \\
\text { GLS } \\
\text { coef/t }\end{array}$ & $\begin{array}{c}(11) \\
\text { GLS } \\
\text { coef/t }\end{array}$ \\
\hline $\mathrm{CT}_{\mathrm{t}}$ & $\begin{array}{r}0.005^{\star * *} \\
(7.222)\end{array}$ & $\begin{array}{r}0.005^{\star \star *} \\
(7.312)\end{array}$ & $\begin{array}{c}0.005^{\star \star \star} \\
(7.523)\end{array}$ & $\begin{array}{r}0.005^{\star \star \star} \\
(7.875)\end{array}$ & $\begin{array}{c}0.005^{\star \star \star} \\
(7.237)\end{array}$ & $\begin{array}{r}0.005^{\star * *} \\
(7.157)\end{array}$ & $\begin{array}{r}0.005^{\star \star *} \\
(7.455)\end{array}$ & $\begin{array}{c}0.005^{\star \star \star} \\
(7.359)\end{array}$ & $\begin{array}{r}0.005^{\star * *} \\
(7.687)\end{array}$ & $\begin{array}{r}0.005^{\star * *} \\
(7.698)\end{array}$ & $\begin{array}{r}0.005^{\star * *} \\
(7.403)\end{array}$ \\
\hline $\mathrm{PET}_{\mathrm{t}}$ & $\begin{array}{c}0.011^{\star * *} \\
(3.701)\end{array}$ & $\begin{array}{c}0.011^{\star * *} \\
(3.709)\end{array}$ & $\begin{array}{c}0.011^{* * *} \\
(3.612)\end{array}$ & $\begin{array}{c}0.011^{* * *} \\
(3.662)\end{array}$ & $\begin{array}{c}0.011^{\star \star *} \\
(3.917)\end{array}$ & $\begin{array}{c}0.011^{* * *} \\
(3.623)\end{array}$ & $\begin{array}{c}0.011^{\star * *} \\
(3.711)\end{array}$ & $\begin{array}{c}0.011^{\star * *} \\
(3.689)\end{array}$ & $\begin{array}{c}0.011^{\text {***}} \\
(3.917)\end{array}$ & $\begin{array}{c}0.011^{* * *} \\
(3.772)\end{array}$ & $\begin{array}{r}0.011^{* * *} \\
(3.709)\end{array}$ \\
\hline PTCA $_{t}$ & $\begin{array}{l}-0.011^{\star \star} \\
(-2.578)\end{array}$ & $\begin{array}{l}-0.011^{* *} \\
(-2.448)\end{array}$ & $\begin{array}{l}-0.011^{\star *} \\
(-2.445)\end{array}$ & $\begin{array}{l}-0.012^{* *} \\
(-2.625)\end{array}$ & $\begin{array}{l}-0.011^{* *} \\
(-2.447)\end{array}$ & $\begin{array}{l}-0.011^{\star \star} \\
(-2.425)\end{array}$ & $\begin{array}{l}-0.011^{* *} \\
(-2.442)\end{array}$ & $\begin{array}{l}-0.011^{\star *} \\
(-2.504)\end{array}$ & $\begin{array}{l}-0.011^{\star *} \\
(-2.342)\end{array}$ & $\begin{array}{l}-0.011^{\star *} \\
(-2.445)\end{array}$ & $\begin{array}{l}-0.011^{\star *} \\
(-2.650)\end{array}$ \\
\hline $\mathrm{PACE}_{t}$ & $\begin{array}{r}0.008 \\
(0.471)\end{array}$ & $\begin{array}{r}0.008 \\
(0.377)\end{array}$ & $\begin{array}{r}0.008 \\
(0.371)\end{array}$ & $\begin{array}{r}0.008 \\
(0.371)\end{array}$ & $\begin{array}{r}0.008 \\
(0.371)\end{array}$ & $\begin{array}{r}0.008 \\
(0.371)\end{array}$ & $\begin{array}{r}0.008 \\
(0.371)\end{array}$ & $\begin{array}{r}0.008 \\
(0.371)\end{array}$ & $\begin{array}{r}0.008 \\
(0.371)\end{array}$ & $\begin{array}{r}0.008 \\
(0.371)\end{array}$ & $\begin{array}{r}0.008 \\
(0.371)\end{array}$ \\
\hline $\log \left(\mathrm{INCOME}_{t}\right)$ & $\begin{array}{r}0.112 \\
(0.067)\end{array}$ & $\begin{array}{r}0.108 \\
(0.055)\end{array}$ & $\begin{array}{r}0.109 \\
(0.061)\end{array}$ & $\begin{array}{r}0.111 \\
(0.062)\end{array}$ & $\begin{array}{r}0.109 \\
(0.058)\end{array}$ & $\begin{array}{r}0.112 \\
(0.051)\end{array}$ & $\begin{array}{r}0.107 \\
(0.049)\end{array}$ & $\begin{array}{r}0.109 \\
(0.050)\end{array}$ & $\begin{array}{r}0.107 \\
(0.042)\end{array}$ & $\begin{array}{r}0.110 \\
(0.046)\end{array}$ & $\begin{array}{r}0.108 \\
(0.045)\end{array}$ \\
\hline EDUCATION $_{\mathrm{t}}$ & $\begin{array}{l}-0.002^{* *} \\
(-2.232)\end{array}$ & $\begin{array}{l}-0.002^{* *} \\
(-2.221)\end{array}$ & $\begin{array}{l}-0.002^{\star *} \\
(-2.033)\end{array}$ & $\begin{array}{l}-0.002^{* *} \\
(-2.207)\end{array}$ & $\begin{array}{l}-0.002^{\star *} \\
(-2.247)\end{array}$ & $\begin{array}{l}-0.002^{* *} \\
(-2.364)\end{array}$ & $\begin{array}{l}-0.002^{* *} \\
(-2.432)\end{array}$ & $\begin{array}{l}-0.002^{* *} \\
(-2.442)\end{array}$ & $\begin{array}{l}-0.002^{* *} \\
(-2.527)\end{array}$ & $\begin{array}{l}-0.002^{* *} \\
(-2.311)\end{array}$ & $\begin{array}{l}-0.002^{\star \star} \\
(-2.228)\end{array}$ \\
\hline $\mathrm{ELDERLY}_{\mathrm{t}}$ & $\begin{array}{c}2.274^{*} \\
(1.869)\end{array}$ & $\begin{array}{c}2.125^{*} \\
(1.828)\end{array}$ & $\begin{array}{c}2.138^{*} \\
(1.884)\end{array}$ & $\begin{array}{c}2.311^{*} \\
(1.756)\end{array}$ & $\begin{array}{c}2.142^{*} \\
(1.796)\end{array}$ & $\begin{array}{c}2.140^{*} \\
(1.822)\end{array}$ & $\begin{array}{c}2.521^{*} \\
(1.744)\end{array}$ & $\begin{array}{c}2.143^{*} \\
(1.735)\end{array}$ & $\begin{array}{c}2.231^{*} \\
(1.729)\end{array}$ & $\begin{array}{c}2.251^{*} \\
(1.756)\end{array}$ & $\begin{array}{c}2.092^{*} \\
(1.785)\end{array}$ \\
\hline UNEMPLOYMENT $T_{t}$ & $\begin{array}{r}-1.180 \\
(-1.518)\end{array}$ & $\begin{array}{r}-1.065 \\
(-1.418)\end{array}$ & $\begin{array}{r}-1.024 \\
(-1.563)\end{array}$ & $\begin{array}{r}-1.032 \\
(-1.435)\end{array}$ & $\begin{array}{r}-1.083 \\
(-1.452)\end{array}$ & $\begin{array}{r}-1.075 \\
(-1.475)\end{array}$ & $\begin{array}{r}-1.072 \\
(-1.493)\end{array}$ & $\begin{array}{r}-1.063 \\
(-1.494)\end{array}$ & $\begin{array}{r}-1.084 \\
(-1.521)\end{array}$ & $\begin{array}{r}-1.086 \\
(-1.602)\end{array}$ & $\begin{array}{r}-1.069 \\
(-1.558)\end{array}$ \\
\hline SPECIALIST $_{t}$ & $\begin{array}{c}0.128^{\star \star \star} \\
(7.713)\end{array}$ & $\begin{array}{c}0.129^{\star \star *} \\
(7.796)\end{array}$ & $\begin{array}{c}0.127^{\star \star \star} \\
(7.963)\end{array}$ & $\begin{array}{c}0.125^{\star \star \star} \\
(7.462)\end{array}$ & $\begin{array}{r}0.128^{\star \star \star} \\
(7.935)\end{array}$ & $\begin{array}{r}0.129^{\star \star *} \\
(7.425)\end{array}$ & $\begin{array}{r}0.126^{\star \star *} \\
(7.517)\end{array}$ & $\begin{array}{c}0.128^{\star \star \star} \\
(7.378)\end{array}$ & $\begin{array}{c}0.128^{\text {***}} \\
(7.728)\end{array}$ & $\begin{array}{c}0.127^{\star \star * *} \\
(7.893)\end{array}$ & $\begin{array}{r}0.128^{\star \star *} \\
(7.957)\end{array}$ \\
\hline $\mathrm{HMO}_{\mathrm{t}}$ & $\begin{array}{l}-0.001^{* *} \\
(-2.714)\end{array}$ & $\begin{array}{l}-0.001^{* *} \\
(-2.219)\end{array}$ & $\begin{array}{l}-0.001^{* *} \\
(-2.345)\end{array}$ & $\begin{array}{l}-0.001^{* *} \\
(-2.549)\end{array}$ & $\begin{array}{l}-0.001^{* *} \\
(-2.372)\end{array}$ & $\begin{array}{l}-0.001^{\star *} \\
(-2.341)\end{array}$ & $\begin{array}{l}-0.001^{* *} \\
(-2.298)\end{array}$ & $\begin{array}{l}-0.001^{* *} \\
(-2.256)\end{array}$ & $\begin{array}{l}-0.001^{\text {** }} \\
(-2.384)\end{array}$ & $\begin{array}{l}-0.001^{* *} \\
(-2.355)\end{array}$ & $\begin{array}{l}-0.001^{\text {** }} \\
(-2.589)\end{array}$ \\
\hline $\mathrm{HIGHDED}_{\mathrm{t}}$ & $\begin{array}{r}0.002 \\
(0.930)\end{array}$ & $\begin{array}{r}0.002 \\
(0.935)\end{array}$ & $\begin{array}{r}0.002 \\
(0.725)\end{array}$ & $\begin{array}{r}0.002 \\
(0.630)\end{array}$ & $\begin{array}{r}0.002 \\
(0.752)\end{array}$ & $\begin{array}{r}0.002 \\
(0.831)\end{array}$ & $\begin{array}{r}0.002 \\
(1.102)\end{array}$ & $\begin{array}{r}0.002 \\
(0.883)\end{array}$ & $\begin{array}{r}0.002 \\
(0.972)\end{array}$ & $\begin{array}{r}0.002 \\
(0.846)\end{array}$ & $\begin{array}{r}0.002 \\
(0.751)\end{array}$ \\
\hline CARDIOLOGY $_{\mathrm{t}-1}$ & $\begin{array}{r}1.739 \\
(0.554)\end{array}$ & & & & & & & & & & \\
\hline $\mathrm{ONCOLOGY}_{\mathrm{t}-1}$ & & $\begin{array}{r}0.737 \\
(-0.072)\end{array}$ & & & & & & & & & \\
\hline NEUROLOGY & & & $\begin{array}{r}-0.217 \\
(-0.261)\end{array}$ & & & & & & & & \\
\hline $\mathrm{RADIOLOGY}_{\mathrm{t}-1}$ & & & & $\begin{array}{l}-0.471 \\
(-0.28)\end{array}$ & & & & & & & \\
\hline ORTHOPEDICS $_{\mathrm{t}-1}$ & & & & & $\begin{array}{r}-0.223 \\
(-0.897)\end{array}$ & & & & & & \\
\hline PATENT $_{\mathrm{t}-1}$ & & & & & & $\begin{array}{r}0.001 \\
(0.228)\end{array}$ & & & & & \\
\hline EMPLOYEES $_{\mathrm{t}-1}$ & & & & & & & $\begin{array}{r}0.000 \\
(0.006)\end{array}$ & & & & \\
\hline $\mathrm{NEIGHBOUR}_{\mathrm{t}-1}{ }^{\mathrm{CT}}$ & & & & & & & & $\begin{array}{r}0.002 \\
(0.154)\end{array}$ & & & \\
\hline NEIGHBOUR ${ }_{\mathrm{t}-1}{ }^{\text {PET }}$ & & & & & & & & & $\begin{array}{r}0.002 \\
(0.053)\end{array}$ & & \\
\hline $\mathrm{NEIGHBOUR}_{\mathrm{t}-1}{ }^{\mathrm{PTCA}}$ & & & & & & & & & & $\begin{array}{r}0.002 \\
(0.128)\end{array}$ & \\
\hline NEIGHBOUR t-1 $^{\text {PACE }}$ & & & & & & & & & & & $\begin{array}{r}0.002 \\
(0.078)\end{array}$ \\
\hline
\end{tabular}


Table 1: Variables for the cost equation (All variables were reported at two levels: canton (c) and year $(\mathrm{t}))$

\begin{tabular}{|c|c|c|c|}
\hline Variable category & & Variable definition & Data source \\
\hline EXPLAINED VARIABLES & COSTS & $\begin{array}{l}\text { Per capita health expenditures (for adults) covered by basic health insurance + } \\
\text { out-of-pocket expenditures in basic health insurance (i.e. deductible and co- } \\
\text { insurance) expressed in year } 2007 \text { constant Swiss Francs }\end{array}$ & FOPH \\
\hline \multicolumn{4}{|c|}{ EXPLANATORY VARIABLES } \\
\hline \multirow[t]{4}{*}{ Technology } & $\mathrm{CT}^{*}$ & Number of CT scanners per million inhabitants & $\mathrm{FOPH}^{\mathrm{a}}$ \\
\hline & $\mathrm{PET}^{*}$ & Number of PET scanners per million inhabitants & $\mathrm{FOPH}^{\mathrm{a}}$ \\
\hline & PTCA & $\begin{array}{l}\text { Number of percutaneous transluminal coronary angioplasty (PTCA) facilities } \\
\text { per million inhabitants }\end{array}$ & $\mathrm{SSC}^{\mathrm{b}}$ \\
\hline & PACE & Number of pacemaker facilities per million inhabitants & $\mathrm{SSC}^{\mathrm{c}}$ \\
\hline \multirow[t]{4}{*}{ Demand } & INCOME & Yearly per-capita income (in thousands, year 2007 constant Swiss Francs) & FOS \\
\hline & EDUCATION & $\%$ first-cycle regular track only (i.e. compulsory school) & SHS \\
\hline & ELDERLY & Population age distribution $(\%$ over 65$)$ & FOS \\
\hline & \multicolumn{2}{|c|}{ UNEMPLOYMENTPercentage of unemployed } & FOS \\
\hline Supply & SPECIALIST & Density of specialists working in private practices per 1000 inhabitants & FOPH \\
\hline \multirow[t]{3}{*}{ Insurance } & HMO & $\%$ population with limited choice of providers health insurance & FOPH \\
\hline & HIGHDED & $\begin{array}{l}\% \text { population with higher deductible options in basic insurance ( } 2500 \text { Swiss } \\
\text { Francs) }\end{array}$ & FOPH \\
\hline & DRG & $\mathrm{DRG}=1$ if the DRG system was partially or fully implemented in the canton & CDS \\
\hline
\end{tabular}

FOPH : Federal Office of Public Health

FOS: Federal Office of Statistics

SHS: Swiss Health Survey $(1997,2002,2007)$ conducted by the FOS

SSC: Swiss Society of Cardiology

CDS: Conférence Suisse des directrices et directeurs cantonaux de la santé

${ }^{\mathrm{a}}$ based on the full list of federal licenses granted in Switzerland since the introduction of these technologies.

${ }^{\mathrm{b}}$ information collected since 1987 in a nationwide annual survey by the working group "interventional cardiology and acute coronary syndrome" (Pedrazzini, 1998; Roffi, 1999; Roffi, 2000; Wahl, 2001; Togni, 2002; Schülter et al, 2004; Maeder et al., 2006; Maeder et al., 2007; Maeder et al., 2008; Maeder et al., 2010)

c information collected by the working group "Arrhythmia and Electrophysiology" since 1992 (http://www.pacemaker.ch)

${ }^{*} \mathrm{CT}_{\mathrm{ct}}$ and $\mathrm{PET}_{\mathrm{ct}}$ were corrected for, using the number of months during which each CT and PET device was actually in operation. This data was available thanks to the availability of installation and withdrawal dates (for withdrawn devices). Combined PET/CT devices ("combos") were included in the number of PET scanners, without any consequence on our results.

Table 2: Description of additional variables introduced in the technology equations (All variables were reported at two levels: canton $(\mathrm{c})$ and year $(\mathrm{t}))$

\begin{tabular}{|c|c|c|c|}
\hline Variable category & & Variable definition & Data source \\
\hline \multirow[t]{6}{*}{ Medical research } & TOTAL PUBLI & Number $^{\mathrm{a}}$ of medical academic publications per 1000 inhabitants & Scopus \\
\hline & CARDIOLOGY & Number ${ }^{\mathrm{a}}$ of academic publications in Cardiology per 1000 inhabitants & Scopus \\
\hline & ONCOLOGY & Number ${ }^{\mathrm{a}}$ of academic publications in Oncology per 1000 inhabitants & Scopus \\
\hline & NEUROLOGY & Number $^{\mathrm{a}}$ of academic publications in Neurology per 1000 inhabitants & Scopus \\
\hline & RADIOLOGY & Number ${ }^{a}$ of academic publications in Radiology per 1000 inhabitants & Scopus \\
\hline & ORTHOPEDICS & Number $^{\mathrm{a}}$ of academic publications in Orthopedics per 1000 inhabitants & Scopus \\
\hline \multirow[t]{2}{*}{ Local high-tech industry } & EMPLOYEES & $\begin{array}{l}\text { Number of employees }{ }^{b} \text { in the medical device industry per } 1000 \\
\text { inhabitants }\end{array}$ & FOS \\
\hline & PATENT & Number of patents ${ }^{\mathrm{b}}$ in medical instruments per 1000000 inhabitants & $\begin{array}{l}\text { PATSTAT } \\
\text { REGPAT-EPO }\end{array}$ \\
\hline Other cantons' influence & NEIGHBOUR ${ }^{\mathrm{b}}$. & $\begin{array}{l}\text { Patient mobility weighted number of devices installed in neighboring } \\
\text { cantons }\end{array}$ & FOS \\
\hline $\begin{array}{l}\text { EPO (European Patent Off } \\
\text { a weighted (see Appendix } 2 \\
\text { b see Appendix } 2 \\
\text { b } \\
\text { Dummy variable }\end{array}$ & & & \\
\hline
\end{tabular}


Table 3: Average values for medical research and local high tech industry variables (19962007)

\begin{tabular}{|c|c|c|c|c|c|c|c|c|c|}
\hline canton & & CARDIOLOGY & ONCOLOGY & NEUROLOGY & RADIOLOGY & ORTHOPEDICS & TOTAL PUBLI & EMPLOYEES & PATENT \\
\hline (a) & (b) & & & & & & & & \\
\hline AG & Aargau & 0.003 & 0.008 & 0.003 & 0.011 & 0.007 & 0.035 & 0.456 & 7.025 \\
\hline Al & Appenzell Innerrhoden & 0 & 0 & 0 & 0 & 0 & 0 & 0 & 0 \\
\hline$A R$ & Appenzell Ausserrhoden & 0 & 0 & 0 & 0.002 & 0 & 0.003 & 0.076 & 3.844 \\
\hline BE & Bern & 0.030 & 0.038 & 0.011 & 0.027 & 0.010 & 0.119 & 1.847 & 13.936 \\
\hline $\mathrm{BL}$ & Basel-Landschaft & 0.011 & 0.008 & 0.003 & 0.011 & 0.005 & 0.040 & 2.285 & 18.507 \\
\hline BS & Basel-Stadt & 0.151 & 0.313 & 0.071 & 0.150 & 0.122 & 0.871 & 1.910 & 8.474 \\
\hline FR & Fribourg & 0.007 & 0.007 & 0.008 & 0.011 & 0.006 & 0.045 & 1.582 & 4.111 \\
\hline GE & Geneva & 0.085 & 0.117 & 0.040 & 0.081 & 0.090 & 0.437 & 0.551 & 9.499 \\
\hline GL & Glarus & 0.002 & 0 & 0 & 0.002 & 0 & 0.004 & 0.286 & 22.354 \\
\hline GR & Graubünden & 0.009 & 0.006 & 0.002 & 0.036 & 0.004 & 0.061 & 0.418 & 18.640 \\
\hline JU & Jura & 0.005 & 0 & 0 & 0 & 0 & 0.006 & 0.338 & 13.710 \\
\hline LU & Lucerne & 0.007 & 0.003 & 0.005 & 0.008 & 0.002 & 0.029 & 0.948 & 4.056 \\
\hline $\mathrm{NE}$ & Neuchâtel & 0.006 & 0.011 & 0.006 & 0.011 & 0.008 & 0.044 & 3.963 & 19.398 \\
\hline NW & Nidwalden & 0 & 0 & 0 & 0.001 & 0 & 0 & 0 & 2.058 \\
\hline ow & Obwalden & 0.002 & 0 & 0 & 0 & 0 & 0.002 & 0.425 & 1.646 \\
\hline SG & St. Gallen & 0.006 & 0.014 & 0.003 & 0.008 & 0.009 & 0.047 & 1.238 & 14.670 \\
\hline $\mathrm{SH}$ & Schaffhausen & 0.003 & 0.001 & 0.002 & 0.002 & 0.001 & 0.004 & 4.947 & 50.594 \\
\hline so & Solothurn & 0.002 & 0.001 & 0.001 & 0.004 & 0.001 & 0.005 & 4.767 & 28.129 \\
\hline SZ & Schwyz & 0 & 0.002 & 0 & 0.002 & 0 & 0.004 & 0.789 & 11.320 \\
\hline TG & Thurgau & 0.003 & 0.002 & 0.001 & 0.002 & 0.002 & 0.006 & 1.351 & 8.510 \\
\hline TI & Ticino & 0.005 & 0.032 & 0.003 & 0.004 & 0.002 & 0.050 & 2.578 & 4.814 \\
\hline UR & Uri & 0 & 0 & 0 & 0 & 0 & 0 & 0 & 0 \\
\hline VD & Vaud & 0.063 & 0.090 & 0.028 & 0.047 & 0.050 & 0.285 & 2.311 & 11.680 \\
\hline VS & Valais & 0.002 & 0.008 & 0.002 & 0.002 & 0.001 & 0.015 & 0.311 & 1.568 \\
\hline ZG & Zug & 0.002 & 0.005 & 0.001 & 0.003 & 0.002 & 0.015 & 13.646 & 57.271 \\
\hline $\mathrm{ZH}$ & Zurich & 0.036 & 0.043 & 0.021 & 0.044 & 0.003 & 0.153 & 1.938 & 12.874 \\
\hline
\end{tabular}

(a) Abbreviation

(b) Full name 
Table 4: The determinants of CT and PET scanner adoption

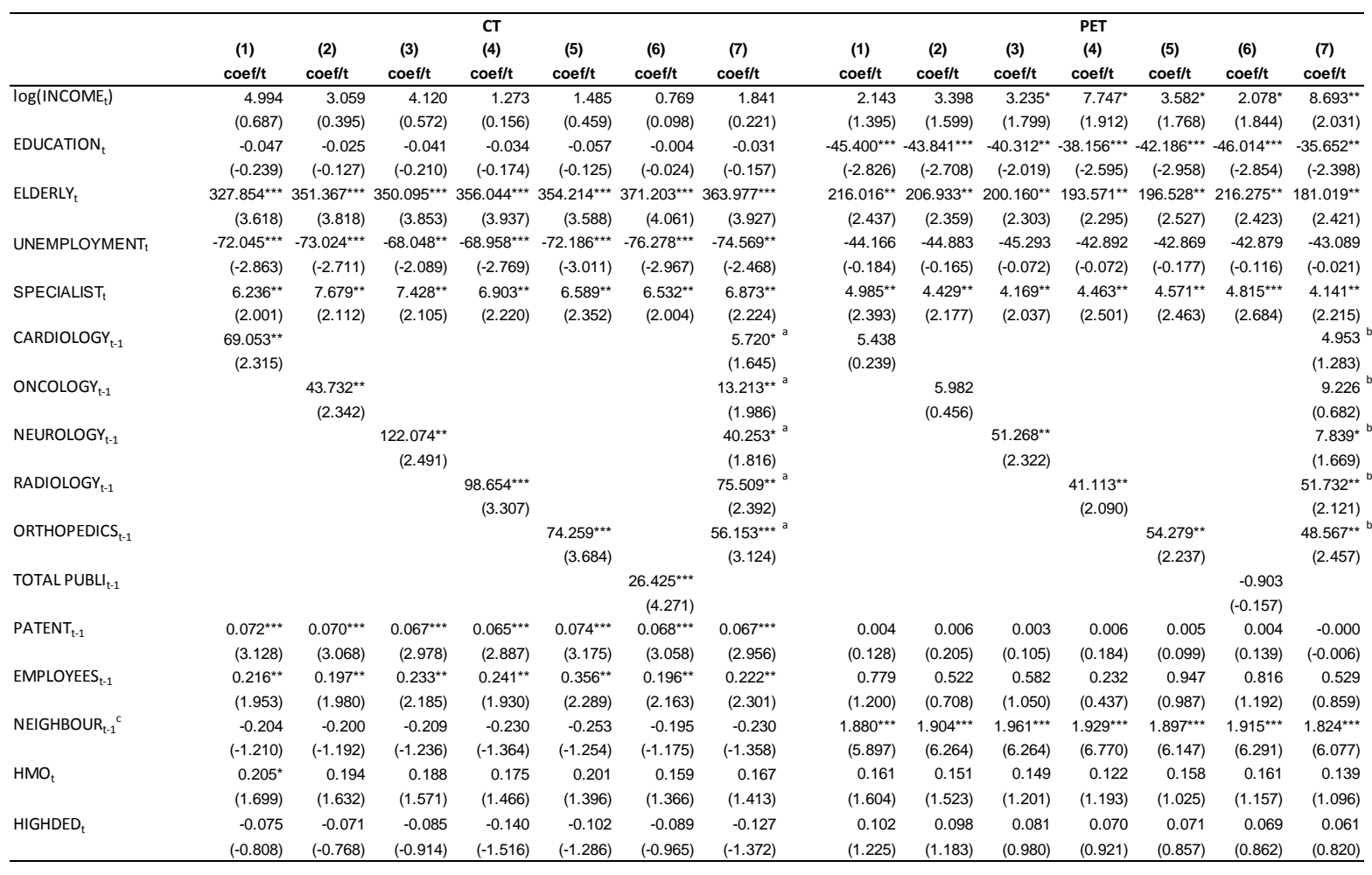

*** significant at the $1 \%$ level, ${ }^{* *}$ significant at the $5 \%$ level, ${ }^{*}$ significant at the $10 \%$ level

All regressions are Tobit panel data with canton fixed effects and time dummies

$\mathrm{N}=312(\mathrm{t}=12)$

${ }^{a}$ Wald test of $\mathrm{HO}$ : the coefficients of the five publication variables are jointly equal to zero: $\mathrm{P}=0.0015$

${ }^{\mathrm{b}}$ Wald test of $\mathrm{HO}$ : the coefficients of the five publication variables are jointly equal to zero: $\mathrm{P}=0.0023$

${ }^{c}$ the variable NEIGHBOUR is specific to each technology (see Appendix 2) 
Table 5: The determinants of PTCA and PACEMAKER capacity adoption

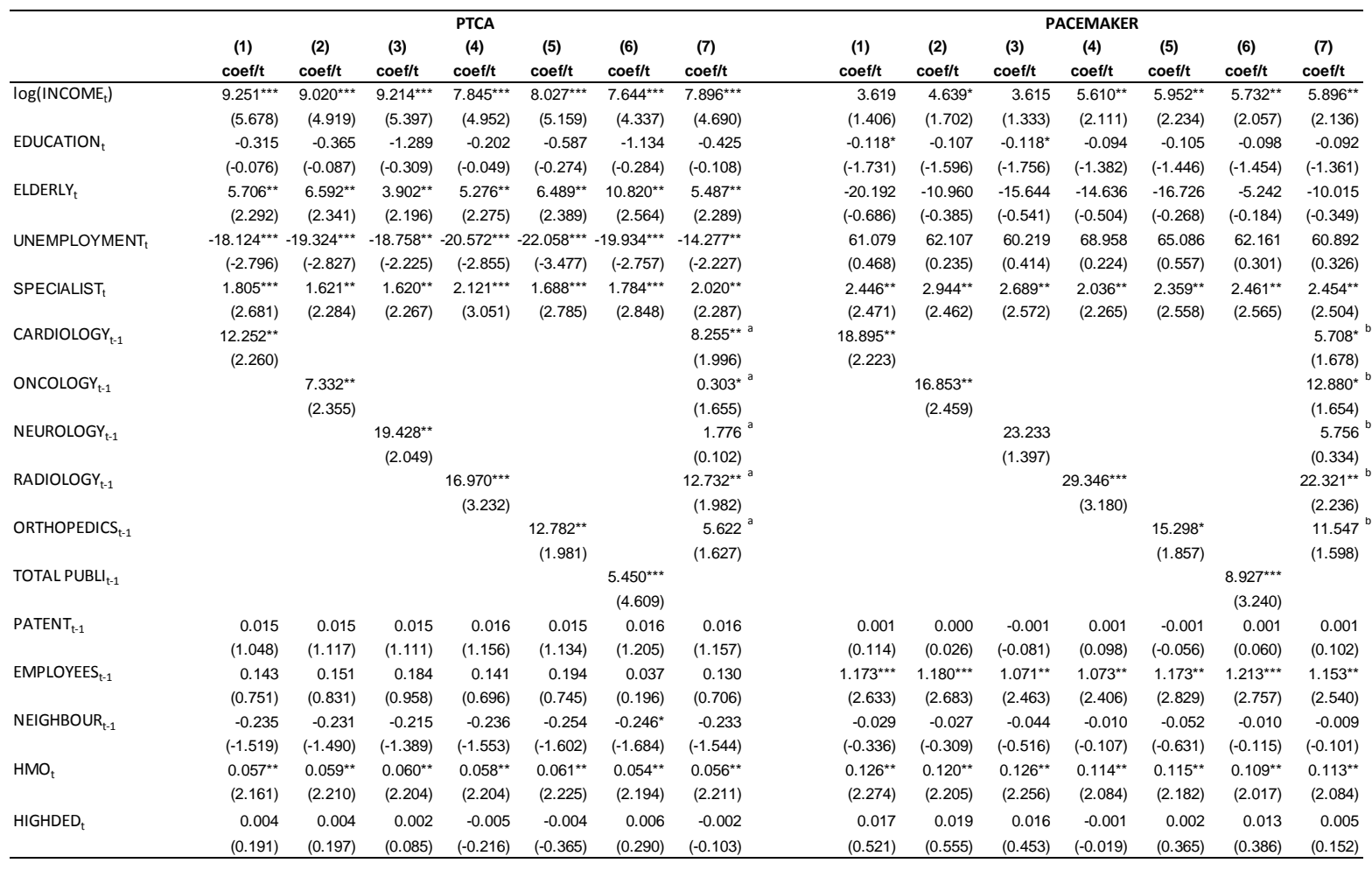

${ }^{* * *}$ significant at the $1 \%$ level, ${ }^{* *}$ significant at the $5 \%$ level, * significant at the $10 \%$ leve

All regressions are Tobit panel data with canton fixed effects and time dummies

$\mathrm{N}=312(\mathrm{t}=12)$

${ }^{\mathrm{a}}$ Wald test of $\mathrm{HO}$ : the coefficients of the five publication variables are jointly equal to zero: $\mathrm{P}=0.0015$

${ }^{b}$ Wald test of $\mathrm{HO}$ : the coefficients of the five publication variables are jointly equal to zero: $\mathrm{P}=0.0023$

${ }^{c}$ the variable NEIGHBOUR is specific to each technology (see Appendix 2) 
Table 6: Influence of medical technologies on total insurance costs

\begin{tabular}{|c|c|c|c|c|c|c|c|}
\hline & $\begin{array}{c}(1) \\
\text { GLS } \\
\text { coef/t }\end{array}$ & $\begin{array}{c}\text { (2) } \\
\text { coef/t }\end{array}$ & $\begin{array}{c}\text { (3) } \\
\text { coef/t }\end{array}$ & $\begin{array}{c}\text { (4) } \\
\text { IV } \\
\text { coef/t }\end{array}$ & $\begin{array}{c}\text { (5) } \\
\text { coef/t }\end{array}$ & $\begin{array}{c}\text { (6) } \\
\text { coef/t }\end{array}$ & $\begin{array}{c}(7) \\
3 S L S \\
\text { coef/t }\end{array}$ \\
\hline $\mathrm{CT}_{\mathrm{t}}$ & $\begin{array}{r}0.005^{* * *} \\
(7.454)\end{array}$ & $\begin{array}{r}0.008^{* * * a} \\
(4.825)\end{array}$ & & & & $\begin{array}{r}0.011^{\star * *} \\
(4.962)\end{array}$ & $\begin{array}{r}0.012^{\star * \star} \\
(6.728)\end{array}$ \\
\hline $\mathrm{PET}_{\mathrm{t}}$ & $\begin{array}{r}0.011^{\star * *} \\
(3.709)\end{array}$ & & $\begin{array}{r}0.017^{\star \star \star \mathrm{b}} \\
(4.770)\end{array}$ & & & $\begin{array}{c}0.027^{\star \star \star} \\
(3.770)\end{array}$ & $\begin{array}{r}0.0357^{\star * *} \\
(4.451)\end{array}$ \\
\hline PTCA $_{t}$ & $\begin{array}{l}-0.011^{* *} \\
(-2.449)\end{array}$ & & & $\begin{array}{c}-0.033^{* * *} \mathrm{c} \\
(-3.114)\end{array}$ & & $\begin{array}{r}-0.052^{\star * *} \\
(-3.338)\end{array}$ & $\begin{array}{r}-0.053^{\star * *} \\
(-3.177)\end{array}$ \\
\hline PACE $_{t}$ & $\begin{array}{r}0.008 \\
(0.371)\end{array}$ & & & & $\begin{array}{l}0.022^{* d} \\
(1.702)\end{array}$ & $\begin{array}{r}0.021 \\
(1.458)\end{array}$ & $\begin{array}{r}0.018 \\
(1.576)\end{array}$ \\
\hline $\log \left(\mathrm{INCOME}_{\mathrm{t}}\right)$ & $\begin{array}{r}0.109 \\
(0.045)\end{array}$ & $\begin{array}{r}0.176 \\
(1.295)\end{array}$ & $\begin{array}{r}0.148 \\
(1.432)\end{array}$ & $\begin{array}{r}0.230 \\
(1.587)\end{array}$ & $\begin{array}{r}0.247 \\
(1.352)\end{array}$ & $\begin{array}{r}0.361 \\
(1.145)\end{array}$ & $\begin{array}{r}0.378 \\
(1.457)\end{array}$ \\
\hline EDUCATION $_{\mathrm{t}}$ & $\begin{array}{l}-0.002^{* *} \\
(-2.209)\end{array}$ & $\begin{array}{l}-0.002^{\star *} \\
(-2.362)\end{array}$ & $\begin{array}{l}-0.003^{\star *} \\
(-2.162)\end{array}$ & $\begin{array}{l}-0.003^{\star *} \\
(-2.297)\end{array}$ & $\begin{array}{l}-0.002^{* *} \\
(-2.013)\end{array}$ & $\begin{array}{l}-0.002^{* *} \\
(-2.158)\end{array}$ & $\begin{array}{c}-0.002^{* *} \\
(-2.277)\end{array}$ \\
\hline ELDERLY $Y_{t}$ & $\begin{array}{c}2.135^{\star} \\
(1.784)\end{array}$ & $\begin{array}{r}2.690 \\
(1.424)\end{array}$ & $\begin{array}{r}2.527 \\
(1.457)\end{array}$ & $\begin{array}{r}2.355 \\
(1.555)\end{array}$ & $\begin{array}{r}2.421 \\
(1.196)\end{array}$ & $\begin{array}{c}2.004^{*} \\
(1.678)\end{array}$ & $\begin{array}{c}2.367^{\star} \\
(1.712)\end{array}$ \\
\hline UNEMPLOYMENT & $\begin{array}{r}-1.087 \\
(-1.493)\end{array}$ & $\begin{array}{r}-1.186 \\
(-0.989)\end{array}$ & $\begin{array}{r}-1.017 \\
(-1.551)\end{array}$ & $\begin{array}{r}-1.154 \\
(-1.002)\end{array}$ & $\begin{array}{r}-0.768 \\
(-1.430)\end{array}$ & $\begin{array}{r}-1.267 \\
(-1.573)\end{array}$ & $\begin{array}{r}-0.725 \\
(-1.128)\end{array}$ \\
\hline SPECIALIST $_{t}$ & $\begin{array}{r}0.128^{\star * *} \\
(7.713)\end{array}$ & $\begin{array}{r}0.110^{\star * *} \\
(7.887)\end{array}$ & $\begin{array}{r}0.121^{\star * *} \\
(7.999)\end{array}$ & $\begin{array}{r}0.144^{\star * *} \\
(8.810)\end{array}$ & $\begin{array}{r}0.109^{* * *} \\
(7.967)\end{array}$ & $\begin{array}{r}0.125^{\star * *} \\
(6.897)\end{array}$ & $\begin{array}{r}0.125^{\star * \star} \\
(6.133)\end{array}$ \\
\hline $\mathrm{HMO}_{\mathrm{t}}$ & $\begin{array}{l}-0.001^{\text {** }} \\
(-2.219)\end{array}$ & $\begin{array}{l}-0.002^{* *} \\
(-1.949)\end{array}$ & $\begin{array}{l}-0.002^{* *} \\
(-2.469)\end{array}$ & $\begin{array}{l}-0.002^{* *} \\
(-2.013)\end{array}$ & $\begin{array}{l}-0.003^{* *} \\
(-2.219)\end{array}$ & $\begin{array}{l}-0.011^{* *} \\
(-1.990)\end{array}$ & $\begin{array}{c}-0.002^{* *} \\
(-2.493)\end{array}$ \\
\hline $\mathrm{HIGHDED}_{\mathrm{t}}$ & $\begin{array}{r}0.002 \\
(0.935) \\
\end{array}$ & $\begin{array}{r}0.002 \\
(1.397) \\
\end{array}$ & $\begin{array}{r}0.001 \\
(1.292) \\
\end{array}$ & $\begin{array}{r}0.001 \\
(0.332) \\
\end{array}$ & $\begin{array}{r}0.002 \\
(1.231) \\
\end{array}$ & $\begin{array}{r}0.006 \\
(0.454) \\
\end{array}$ & $\begin{array}{r}0.003 \\
(1.001) \\
\end{array}$ \\
\hline $\begin{array}{l}\text { F-statistic that all excluded } \\
\text { instruments are equal to zero }\end{array}$ & & 18.582 & 15.22 & 15.288 & 12.295 & & \\
\hline
\end{tabular}

${ }^{* * *} p<0.01,{ }^{* *} p<0.05,{ }^{*} p<0.1$

All regressions are panel data with canton fixed effects and time dummies

$\mathrm{N}=312$

Col 1: Technology variables are exogeneous

Col 2-5: Technology variables are introduced one by one and instrumented

Col 6: Technology variables are all introduced and instrumented

IV are: cardiology, oncology, neurology, radiology, orthopedics, patent, employees, neighbour

Col 7: Simultaneous system (3SLS)

${ }^{a}$ Davidson-MacKinnon's test (H0 : exogeneity of the technology variable): $p<0.001$

${ }^{b}$ Davidson-MacKinnon's test ( $\mathrm{HO}$ : exogeneity of the technology variable): $p=0.041$

${ }^{c}$ Davidson-MacKinnon's test ( $\mathrm{HO}$ : exogeneity of the technology variable): $p=0.050$

${ }^{d}$ Davidson-MacKinnon's test ( $\mathrm{HO}$ : exogeneity of the technology variable): $p=0.008$ 
Figure 1: Level (2007) and evolution (1996-2007) of monthly per capita healthcare expenditures for adults older than 25 , by canton

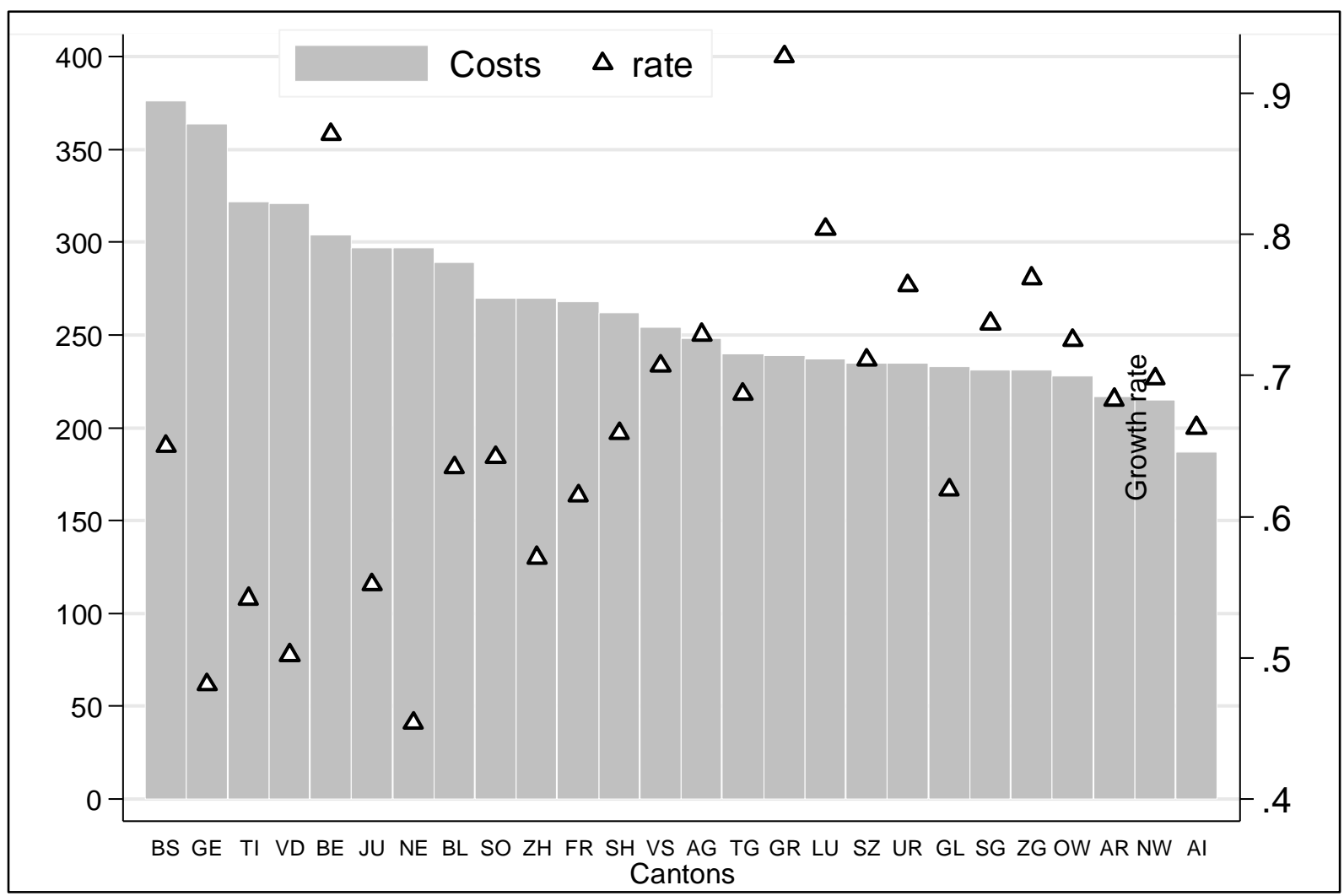


Figure 2: Swiss CT and PET density in 2007, by canton

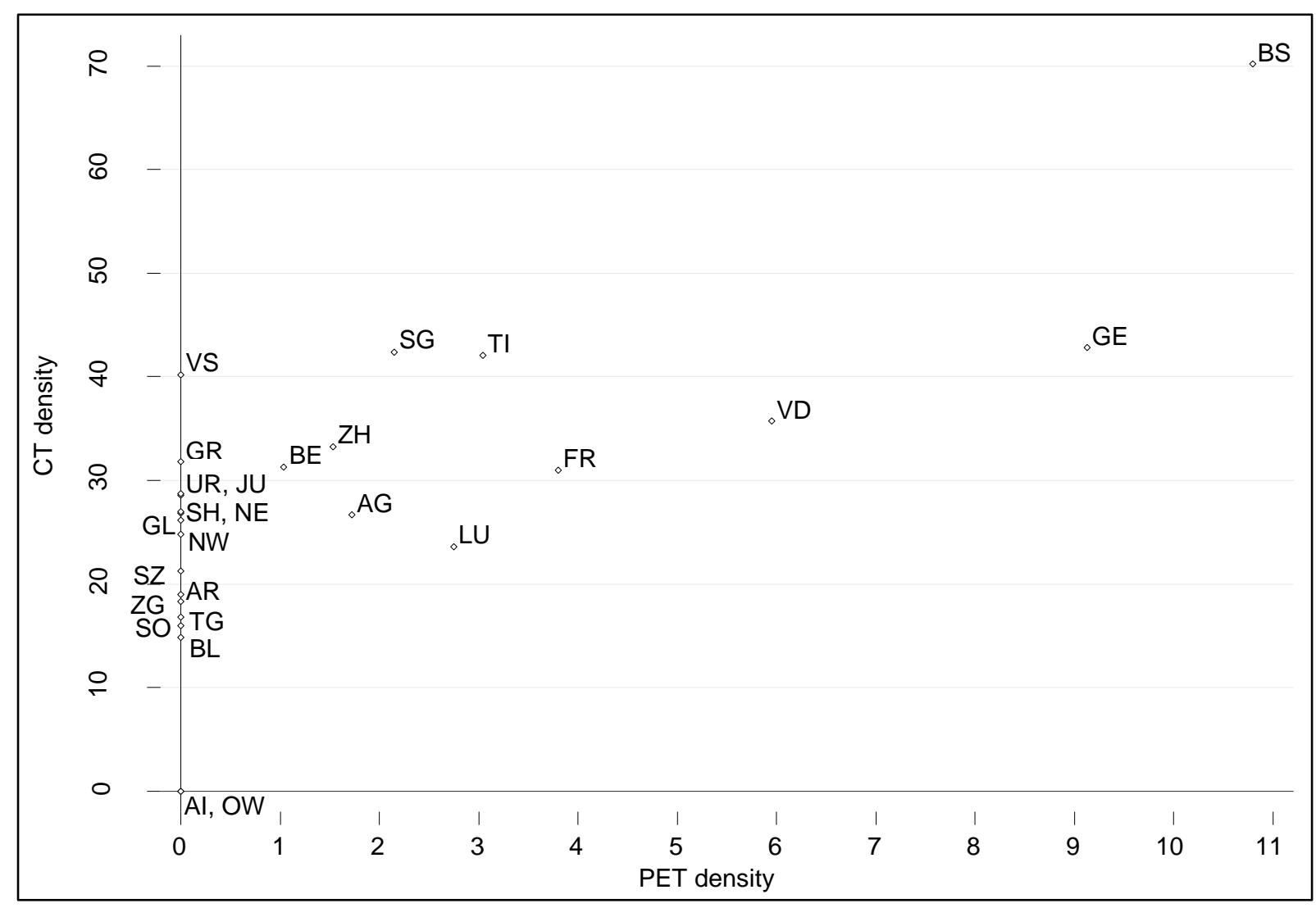


Figure 3: Swiss PTCA and Pacemaker facility density in 2007, by canton

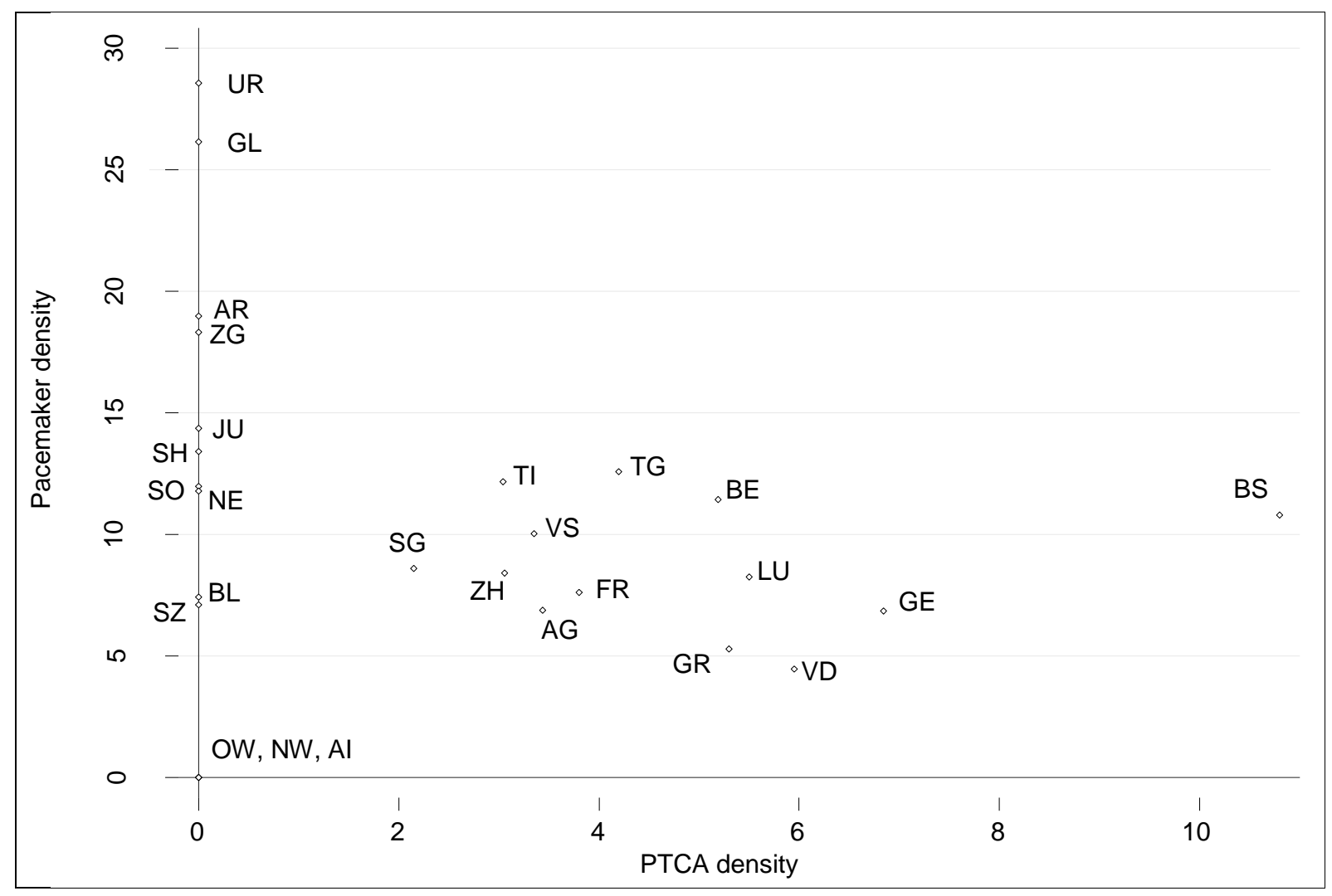




\section{ESSEC Business School}

Avenue Bernard Hirsch

CS 50105 Cergy

95021 Cergy-Pontoise Cedex

France

Tél. + 33 (0) 134433000

Fax + 33 (0)134433001

www.essec.fr

ESSEC Executive Education

CNIT BP 230

92053 Paris-La Défense

France

Têl. + $33(0) 146924900$

Fax +33(0)146924990

www.executive-education.essec.fr

Contact:

ESSEC Asia-Pacific

Research Center

100 Victoria Street

National Library \# 13-02

Singapore 188064

$+33(0) 134433358$

research.center@essec.fr

Têl. + 6568849780

Fax +65 68849781

www.essec.edu/asia 